Research Article

\title{
Study on Model and Tests of Sheet Pile Wall with a Relieving Platform
}

\author{
Ming Zhang, ${ }^{1}$ Wei Wang $\mathbb{D}^{2}{ }^{2}$ Ronghua $\mathrm{Hu}^{3}$ and Ziyi Wang ${ }^{4}$ \\ ${ }^{1}$ Institute of Civil Engineering, Henan University of Engineering, Xianghe Rd 1, Zhengzhou 451191, China \\ ${ }^{2}$ College of Architecture and Urban Planning, Beijing University of Technology, Pingleyuan Rd 100, Beijing 100124, China \\ ${ }^{3}$ Amer International Group Co., Ltd., West Hongli Rd 8133, Shenzhen 518040, China \\ ${ }^{4}$ College of Architecture and Civil Engineering, Beijing University of Technology, Pingleyuan Rd 100, Beijing 100124, China \\ Correspondence should be addressed to Wei Wang; ieeww@bjut.edu.cn
}

Received 4 June 2020; Revised 23 August 2020; Accepted 6 September 2020; Published 18 September 2020

Academic Editor: Hui Yao

Copyright $\odot 2020$ Ming Zhang et al. This is an open access article distributed under the Creative Commons Attribution License, which permits unrestricted use, distribution, and reproduction in any medium, provided the original work is properly cited.

\begin{abstract}
A new type of retaining wall, the sheet pile wall with a relieving platform, is introduced in this paper. Based on the prototype retaining wall with a height of 12 meters, the model tests with a geometric similarity ratio of 7 are designed and we focus on the model production and analysis on the test results. Some comparative analyses between the measured values and the calculation values by using the theoretical calculation method and finite difference method are carried out, including Earth pressure behind the wall, prepile resistance force, the bending moment, and the deformation of rib pillars in the retaining wall. The results show that Earth pressure behind the wall has a linear increase with the depth and lies between Rankine Earth pressure and Earth pressure at rest. Moreover, the prepile resistance force can be approximated by the method, and the bending moment can be also used for approximate calculation by the m method and is larger than the results calculated by the finite difference method. It is also observed that there is a zero-displacement point on the pile bottom, and the Earth pressure above the point behind the pile develops from Earth pressure at rest to the active Earth pressure; the Earth pressure under the point behind the pile develops from Earth pressure at rest to the passive Earth pressure. Therefore, the Earth pressure behind the bottom wall is larger than the calculated value by the Rankine theory. Finally, the displacement of the rib pillars is greater than the calculated results using the finite difference method and exceeds the standard requirements, owing to the failure of the retaining wall, and the unloading board needs to be constructed to improve the retaining wall's behaviour. These findings verify the model's credibility and provide an underpinning for studying the behavior of the retaining wall.
\end{abstract}

\section{Introduction}

Currently, the standard methods that have been used to investigate and analyze the interaction between retaining structure and soil include model tests, centrifugal tests, field tests, analytical methods, and numerical analysis. Compared with the other tests, such as centrifugal tests and field tests, the model tests have the advantages of excellent repeatability, strong operability, and unconstrained field conditions. Thus, they are suitable for studying the various influencing factors on the retaining structure and their complex mechanisms. In addition, the model tests can adjust test parameters or change test conditions and investigate one or several factors intensively to reveal the nature of the problem of retaining structural engineering. Therefore, model testing is considered as the most important means to study complex engineering problems, particularly in the areas of the new retaining structure $[1,2]$.

With regard to the reinforced soil retaining wall (RSW), it has become one of the Earth's retaining structures that can be seen in geotechnical engineering since 1963. The RSW secures structural stability through the frictional force between the foundation and the reinforcement by installing reinforcements and walls simultaneously with the foundations [3]. A series of model tests have been conducted to investigate the failure phenomenon [4-7], the deformation behavior [3, 7-9], and Earth pressure distributions $[9,10]$ of the RSW. Inclined Earth retaining (IER) structure is developed in order to improve the mechanical properties of the existing Earth retaining method. 
IER consists of three main structures, front support, back support, and head binding, and the back support is very effective for the reduction of the Earth pressure acting on the front support and the lateral displacement of IER, which has been confirmed by model tests $[11,12]$. Assembled Earth Retaining wall (AER-wall) using back pile has been developed at Pusan National University. Both cost and time have been significantly reduced because AER-wall can be fabricated in a shop. Also, its stability has been improved with a back-supporting beam reducing Earth pressure, which has been confirmed by laboratory model tests, and the lateral displacement of AER-wall significantly decreases with both inclined wall and back-supporting beams [13]. The field model tests of AER-wall have been performed to confirm that the Earth pressure is considerably reduced compared with the L-shaped retaining wall [14]. A precast concrete double wall (PCDW) system is developed to improve the productivity of conventional retaining wall [15]. The ARE-wall is composed of the PCDW system and retaining wall system, which can contribute to securing integrity, reducing the delay in construction, and improving quality. An overall process for the member design and construction stage of the ARE-wall system has been proposed, and its improvement effects are examined regarding various aspects in comparison to the reinforced concrete method. However, no experimental method has been used to determine the performance of the ARE-wall.

The distribution of Earth pressure behind the cantilever retaining walls subjected to line loads has been predicted by a comparison between the conventional theories of Earth pressure and the finite element method [16]. The magnitude and distribution of lateral Earth pressure of the cantilever retaining walls resting on clayey soil are studied by a series of two-dimensional plane-strain analyses and the finite element method [17]. However, the cantilever retaining wall can be the most economical solution by adding relieving platforms on the backfill side of the wall. The relieving platforms have advantages of decreasing the lateral Earth pressure and increasing the overall stability of the retaining wall. The retaining wall is not a new type of construction in countries such as China, Korea, India, and Russia. Model tests have been performed to determine the distribution of the Earth pressure and confirm the effect of decreasing the lateral Earth pressure on the retaining wall with relieving platform [18-20]. From the model tests, comparisons between the retaining wall with relieving platform and the cantilever retaining wall show that the reduction of the lateral Earth pressure and deformation of wall are indicated clearly on the retaining wall with a relieving platform, and the overall stability is increased by the relieving platform [21]. The length and the location of the platform are the key factors influencing the lateral Earth pressure. A sheet pile retaining wall is composed of a pile, a retaining plate, and a rib pillar. Its advantages include a small space for arrangement and no limitation on bearing capacity of the foundation structure. The behavior of the contiguous bored pile retaining wall supporting system has been investigated using a physical model [22], and a series of plane-strain small-scale model tests on a piled retaining wall embedded in sand under axial loads are performed in the laboratory; and the influence of the penetration depth, pile stiffness, and sand relative density on both ultimate axial capacity and deformation behavior of the piled system has been evaluated [23].

Combining the advantages of the retaining wall with relieving platforms and the sheet pile retaining wall, the sheet pile wall with a relieving platform (shown in Figure 1) has been successfully used in various slope management projects in China. The retaining wall has the following advantages:

(1) It has the advantages of the sheet pile retaining wall, including a small space for arrangement, good safety and reliability, and good durability

(2) The Earth pressure behind the wall under the unloading board is reduced through the unloading effect of the unloading board

(3) The unloading board provides a reverse bending moment to the rib pillars and piles; therefore, the internal force distribution of the retaining wall tends to be reasonable and the mechanical deformation characteristics of the retaining wall are optimized

(4) Due to the unloading effect of the unloading board and its inverse bending moment to the wall, the retaining wall is applicable to higher slope than the cantilever sheet pile retaining wall

(5) Compared with the reinforced soil retaining wall (RSW), the excavation space behind the wall is reduced, which has good adaptability to the site and high safety for long-term use

Currently, both Chinese and international scholars and engineers have used simplified theoretical calculation methods and numerical analysis to determine some parameters and analyze the mechanical, deformation properties of the retaining structure. Theoretical analysis has been used to obtain the ratio between the reasonable unloading board buried depth and board width, as well as the ratio of height between the upper wall and lower wall [24]. Hu et al. [25] developed the computational formula of the range value for unloading board width and computational formula of the minimum pile length. Meanwhile, the validity and credibility of computational formula for the minimum pile length were verified through the data and example analysis. $\mathrm{Hu}$ et al. [26] divided the sheet pile wall with a relieving platform into loaded segment and anchored segment and developed a FEM numerical model to calculate the inner force and deformation of the sheet pile with relieving platform, and the effectiveness of the calculation model was confirmed by using FEM model and fielding monitoring data. $\mathrm{Hu}$ et al. [27] deduced the analytical formula for the deformation of the retaining wall based on elastic foundation beam method and analyzed the influence of the diameter and length of pile, the proportional coefficient of foundation soil resistance coefficient, and the internal friction angle of the backfill on the structural deformation. Their studies show that the length of the unloading board has significant effective lower and upper limit value. 


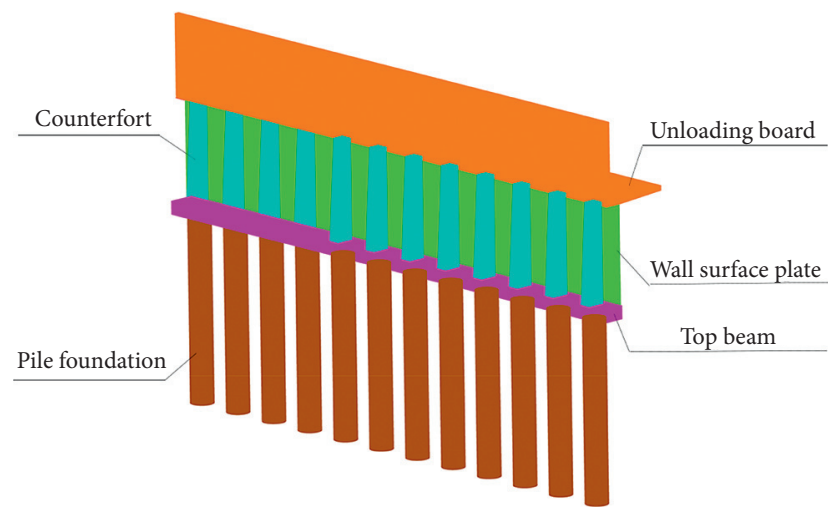

FIGURE 1: 3D schematic diagram of the sheet pile wall with a relieving platform.

However, there is no comprehensive and accurate calculation theory or method for the retaining wall structure. Thus, this research conducted a model test study on the sheet pile wall with a relieving platform and provided a basis for the design principles and calculation method of the retaining wall. In this study, the model pile box and the model structure of the sheet pile wall with a relieving platform were made. A test scheme was developed after determining the model material, model structure and size, model loading equipment, and measurement system. This study found a series of test results, such as the Earth pressure behind the wall, prepile resistance force, the bending moment, and the deformation of rib pillars in the retaining wall. The analysis of the findings verified the credibility of the test model, test data, and the test instrument. A credibility test method was thus provided for studying the mechanical and deformation characteristics of the sheet pile wall with a relieving platform.

\section{General Structure of Sheet Pile Wall with a Relieving Platform}

Currently, in China, the sheet pile walls with the relieving platform are generally used for retaining engineering, and they are ranging between $8.0 \mathrm{~m}$ and $15.0 \mathrm{~m}$. Figure 2 shows the sheet pile wall structure with a relieving platform used in the project with $12 \mathrm{~m}$ support. This wall structure is used as the prototype of the model testing. The mechanical parameters of the retaining wall and characteristic parameters of the retaining wall structure are shown in Tables 1 and 2, respectively.

\section{Similarity Coefficient of the Model}

Using three similar theorems to calculate the similarity coefficient $\lambda_{\mathrm{x}}$ of the same physical quantity in the prototype and the model of the sheet pile wall with a relieving platform [28-32],

$$
\lambda_{\mathrm{x}}=\frac{X_{\mathrm{p}}}{X_{\mathrm{m}}}
$$

In equation (1), $x$ is any physical quantity; the subscripts " $\mathrm{p}$ " and " $\mathrm{m}$ " represent the prototype and the model,

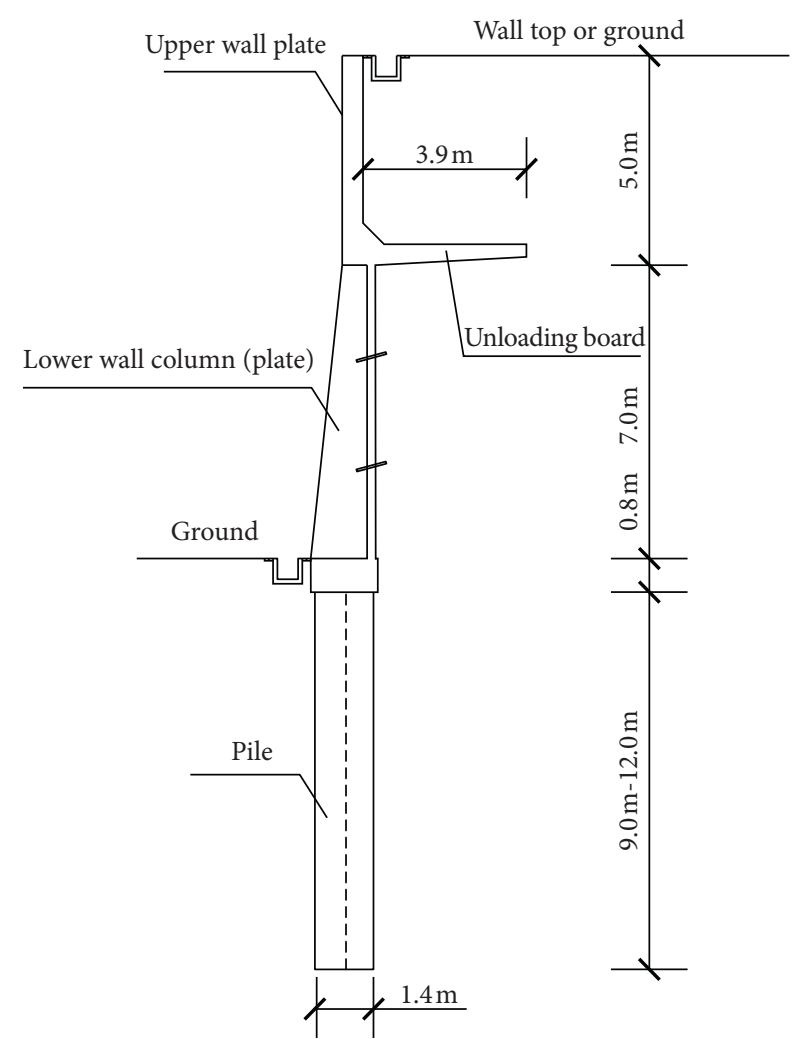

Figure 2: The cross section of sheet pile wall with a relieving platform in a project.

TABLE 1: Mechanical parameters of the sheet pile wall with the relieving platform.

\begin{tabular}{lccccc}
\hline Items & $E(\mathrm{MPa})$ & $\mathrm{M}$ & $\rho\left(\mathrm{kg} / \mathrm{m}^{3}\right)$ & $c(\mathrm{kPa})$ & $\varphi\left(^{\circ}\right)$ \\
\hline Pile foundation & 28000.0 & 0.20 & 2500.0 & - & - \\
Top beam & 28000.0 & 0.20 & 2500.0 & - & - \\
Rib pillar & 28000.0 & 0.20 & 2500.0 & - & - \\
Wall surface plate & 28000.0 & 0.20 & 2500.0 & - & - \\
Unloading board & 28000.0 & 0.20 & 2500.0 & - & - \\
Fill soil (stone powder) & 80.0 & 0.28 & 2400.0 & 1.0 & 35.0 \\
Soil between piles & 30.0 & 0.30 & 1800.0 & 28.0 & 16.0 \\
\hline
\end{tabular}

respectively. According to the catalogue of scaling laws [33], the theory of elasticity, the theory of soil strength and a load of sheet pile wall with a relieving platform, and the similar relationship of the main physical quantities are shown in Table 3 (the results are derived from Iai [34]). The geometric similarity coefficient $\lambda$ is 7 in this test. Iai [34] studied the similarity relationship of each physical quantity in model test, and the results showed that only the geometric similarity coefficient $\lambda$, density similarity coefficient $\lambda_{\rho}$, and strain similarity coefficient $\lambda_{\varepsilon}$ were independent in the physical quantities in Table 3.

\section{Construction of the Test Model}

4.1. Model Materials. When soil materials are being selected, the similarity coefficient $\lambda \gamma$ of the soil specific gravity is made close to 1 in the prototype; that is, the 
TABLE 2: Characteristic parameters of the sheet pile wall with the relieving platform.

\begin{tabular}{|c|c|c|c|c|c|c|c|}
\hline Components & $\begin{array}{c}\text { Concrete } \\
\text { no. }\end{array}$ & $\begin{array}{c}\text { Section } \\
\text { dimension } \\
(\mathrm{m})\end{array}$ & $\begin{array}{c}\text { Section } \\
\text { moment of } \\
\text { inertia }\left(\mathrm{m}^{4}\right) \\
\end{array}$ & $\begin{array}{l}\text { Stiffness } \\
\left(\mathrm{N} \cdot \mathrm{m}^{2}\right)(\mathrm{E})\end{array}$ & $\begin{array}{l}\text { Stiffness in } \\
\text { unit width } \\
\left(\mathrm{N} \cdot \mathrm{m}^{2} / \mathrm{m}\right)\end{array}$ & $\begin{array}{l}\text { Calculative } \\
\text { width }(\mathrm{m})\end{array}$ & Remarks \\
\hline $\begin{array}{l}\text { Pile } \\
\text { foundation }\end{array}$ & $\mathrm{C} 25$ & $\begin{array}{c}\text { Pile diameter } \\
1.4\end{array}$ & 0.21 & 4.99 & $1.63 E 9$ & 3 & $\begin{array}{l}\text { Reinforcement ratio is } \\
\text { considered as the calculating } \\
\text { moment of inertia }\end{array}$ \\
\hline Rib pillar & $\mathrm{C} 25$ & $0.8 \times 1.1$ & 0.05 & 1.49 & $4.67 E 8$ & 3 & $\begin{array}{c}\text { Upper base multiplied by the } \\
\text { lower base for equivalent } \\
\text { calculation }\end{array}$ \\
\hline $\begin{array}{l}\text { Unloading } \\
\text { board }\end{array}$ & $\mathrm{C} 25$ & $0.5 \times 3.0$ & 0.03125 & 8.758 & $2.92 E 8$ & 3 & $\begin{array}{l}\text { Thickness multiplied by the } \\
\text { width }\end{array}$ \\
\hline Top beam & $\mathrm{C} 25$ & $1.6 \times 0.8$ & 0.0683 & 1.919 & - & - & $\begin{array}{l}\text { Rectangle, length multiplied } \\
\text { by the height }\end{array}$ \\
\hline $\begin{array}{l}\text { Wall surface } \\
\text { plate }\end{array}$ & $\mathrm{C} 25$ & $12 \times 0.3$ & 0.0027 & 7.568 & $2.52 E 8$ & 3 & $\begin{array}{c}\text { Rectangle, height multiplied } \\
\text { by the thickness }\end{array}$ \\
\hline
\end{tabular}

TABLE 3: The similar relationship of the main physical quantities.

\begin{tabular}{lccc}
\hline Symbols & Physical quantity & Similarity relation (prototype: model) & Test value \\
\hline 1 & Length (geometry size) & $\Lambda e$ & 7 \\
$\rho$ & Density & $\lambda_{\rho}$ & 1 \\
$q$ & Load (area force) & $\lambda \lambda_{\rho}$ & 7 \\
$\varepsilon$ & Strain & $\lambda_{\varepsilon}$ & 1 \\
$\sigma$ & Stress & $\lambda \lambda_{\rho}$ & 7 \\
$\mathrm{~s}$ & Displacement & $\lambda \lambda_{\varepsilon}$ & 7 \\
EI & Flexural rigidity with unit width & $\lambda^{4} \lambda_{\rho} / \lambda \varepsilon$ & 2401 \\
$\mathrm{M}$ & Bending moment with unit width & $\lambda^{3} \lambda_{\rho}$ & 343 \\
$\varphi$ & Internal friction angle of soil & $\lambda_{\varphi}$ & 1 \\
\hline
\end{tabular}

similarity coefficient $\lambda_{\mathrm{E}}$ of the elastic modulus is made close to 7, and the medium-coarse sand is selected as the fill soil and soil between piles in the model test. A series of physical and mechanical tests including specific gravity test, the maximum and minimum dry density test, direct shear test, particle separation test, and water content test are completed in the geotechnical laboratory of Civil Engineering Department of Shenzhen University in China. The physical and mechanical parameters of the medium-coarse sand are as shown in Table 4 . The grading curve is shown in Figure 3.

Steel, polymethyl methacrylate (PMMA), gypsum, and fine-aggregate reinforced concrete are considered when the model material for the retaining wall is selected. The structural material of the prototype retaining wall is the reinforced concrete, as it is in an elastic state under normal working conditions. Owing to its characteristic of being easy to produce and simulate, a steel is chosen as the model material for the retaining wall. Corresponding to each part of the prototype structure, the circular steel pipe pile is used, while the square steel pipe is applied in the pillar ribs. The channel steel and steel plates are applied in the unloading board.

\subsection{Model Structure Size}

4.2.1. Size and Construction of the Model Test Box. The prototype retaining wall is $12 \mathrm{~m}$ high; the piles have $3 \mathrm{~m}$ spacing, and the filling height is $12 \mathrm{~m}$. The horizontal width of the prototype retaining wall is $12.5 \mathrm{~m}$. Accordingly, the model test box is $2.0 \mathrm{~m}$ wide, and 4 piles are simulated. The longitudinal length of the test box is determined by the spatial dimension calculated using the sliding plane of the active Earth pressure and the passive Earth pressure. The relationship between the prototype size and model size is shown in Table 5 and Figure 4.

In this study, the size of the model test box is $6.5 \mathrm{~m}$ (length) $\times 2.0 \mathrm{~m}$ (width) $\times 4.0 \mathrm{~m}$ (height). The real figure of the model test box is shown in Figure 5. Due to the high structural model of the retaining wall, the model box is fixed firmly into the ground for easy testing and operation. Four anchor fixing bolts are prescrewed into the top of the model test box to secure the reaction frame.

4.2.2. Size of Model Structure and Production. According to the characteristic parameters of the retaining wall in Table 2 and the similarity relationship in Table 3, the characteristic parameters of the retaining wall structure are shown in Table 6.

In the equivalent calculation, several aspects should be stated [35]:

(1) Assume that $(\mathrm{EI})_{\mathrm{p}}$ and $(\mathrm{EI})_{\mathrm{m}}$ are the actual stiffnesses of the prototype structure and model structure, respectively, while $(\mathrm{EI})^{\prime}{ }_{\mathrm{p}}$ and $(\mathrm{EI})^{\prime}{ }_{\mathrm{m}}$ are the stiffnesses of unit width in the prototype structure and model 
TABle 4: Physical and mechanical parameters of the medium-coarse sand.

\begin{tabular}{lcccccccc}
\hline Items & $E(\mathrm{MPa})$ & $\mathrm{M}$ & $\rho_{\mathrm{d}}\left(\mathrm{kg} / \mathrm{m}^{3}\right)$ & $\varphi\left({ }^{\circ}\right)$ & $\begin{array}{c}\text { Specific } \\
\text { gravity }\end{array}$ & $\begin{array}{c}\text { Moisture } \\
\text { content }(\%)\end{array}$ & $\begin{array}{c}\text { Coefficient of } \\
\text { uniformity, Cu }\end{array}$ & Coefficient of curvature, Cc \\
\hline Medium-coarse sand & 15 & 0.30 & 1591.0 & 35.8 & 2.653 & 12 & 2.86 & 0.92 \\
\hline
\end{tabular}

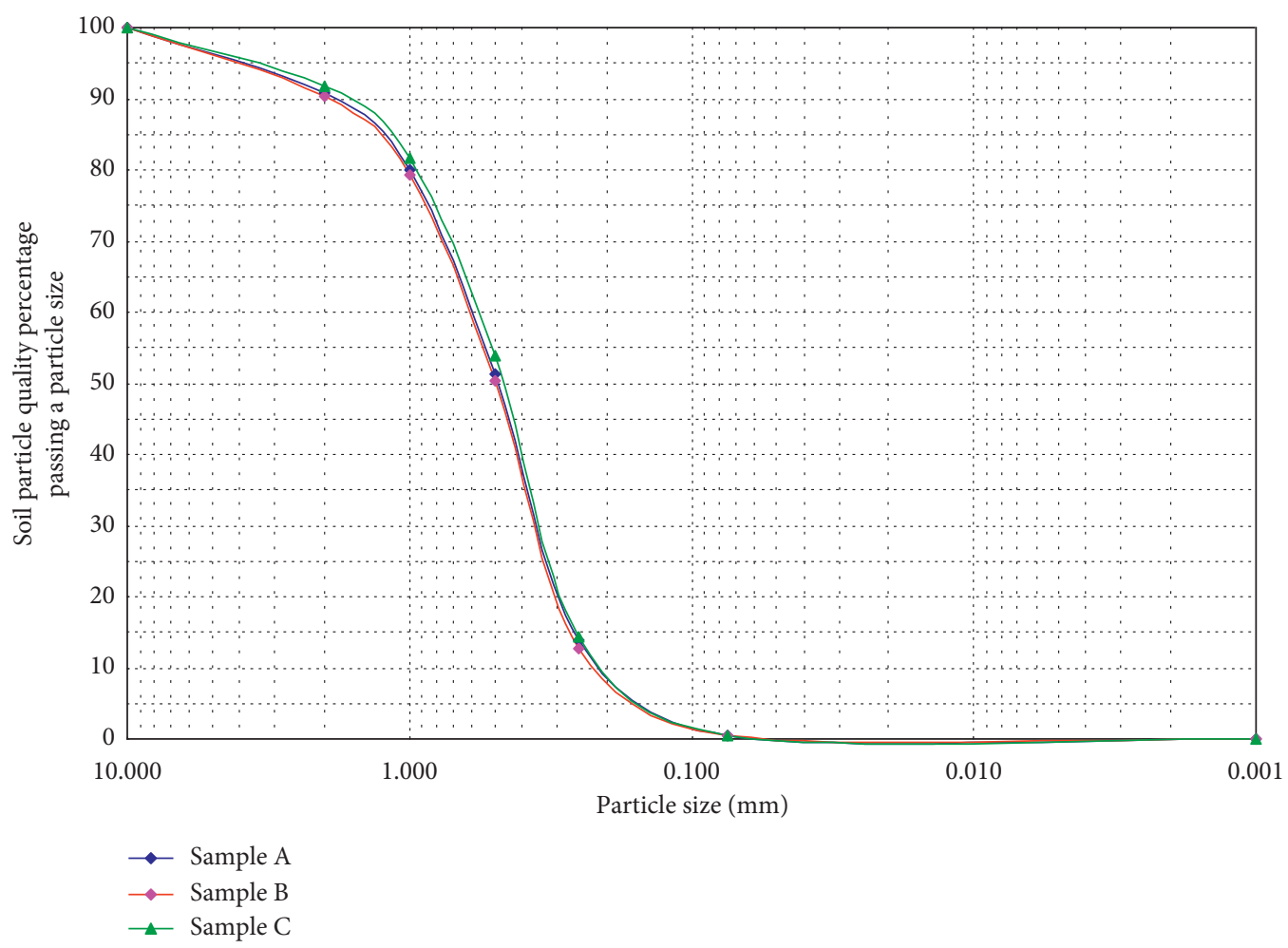

Figure 3: Grading curve.

TABLE 5: The relationship between the prototype size and model size.

\begin{tabular}{|c|c|c|c|c|c|c|}
\hline \multirow[b]{2}{*}{ Items } & \multirow{2}{*}{$\begin{array}{l}\text { Pile } \\
\text { length } \\
(\mathrm{m})\end{array}$} & \multirow{2}{*}{$\begin{array}{l}\text { Height of the } \\
\text { retaining wall } \\
\text { (m) }\end{array}$} & \multirow[b]{2}{*}{$\begin{array}{l}\text { Horizontal } \\
\text { width }(\mathrm{m})\end{array}$} & \multicolumn{2}{|c|}{$\begin{array}{l}\text { Longitudinal length } \\
\qquad(\mathrm{m})\end{array}$} & \multirow[b]{2}{*}{ Remarks } \\
\hline & & & & $\begin{array}{l}\text { Length } \\
\text { before } \\
\text { the pile }\end{array}$ & $\begin{array}{l}\text { Length } \\
\text { after the } \\
\text { pile }\end{array}$ & \\
\hline Prototype & 12.0 & 12.0 & $\begin{array}{l}12.5 \text { (width of } 4 \\
\text { piles) }\end{array}$ & - & - & \multirow{2}{*}{$\begin{array}{l}\text { The longitudinal length of the model is calculated and } \\
\text { determined by the sand parameters }\end{array}$} \\
\hline Model & 1.70 & 1.70 & $\begin{array}{c}2.0 \text { (width of } 4 \\
\text { piles) }\end{array}$ & 3.75 & 2.75 & \\
\hline
\end{tabular}

structure, respectively. The following equation is shown in Table 3:

$$
(\mathrm{EI})^{\prime} \mathrm{m}=\frac{(\mathrm{EI})^{\prime} p}{\left(\left(\rho_{\text {concrete }} / \rho_{\text {steel }}\right) \lambda^{4}\right)}
$$

(2) The unit width of the model is $1 / 7$ of the prototype width, that is, $3 \mathrm{~m} / 7 \approx 0.43 \mathrm{~m}$. In order to expand the measurement displacement and facilitate the generating of the structural model, the pile spacing in the model is 0.6 meters.

(3) The unit width stiffness of a $5 \mathrm{~mm}$ thick steel plate is negligible, compared to the unit width stiffness of the channel steel.

(4) In the equivalent calculation of the retaining plate, the parameters of the wooden board are as follows [36]: $E_{\text {board }}=2.75 \mathrm{GPa}$ and $\rho_{\text {board }}=600 \mathrm{~kg} /$ $\mathrm{m}^{3}$. 


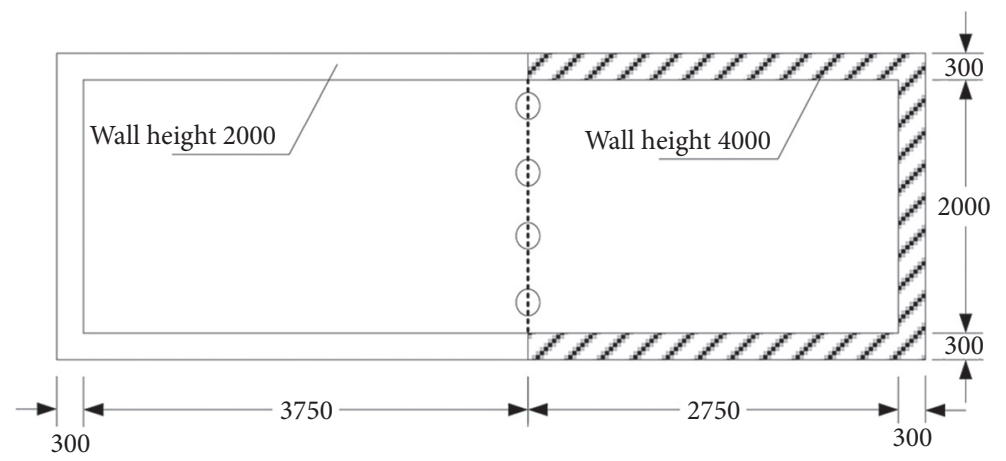

(a)

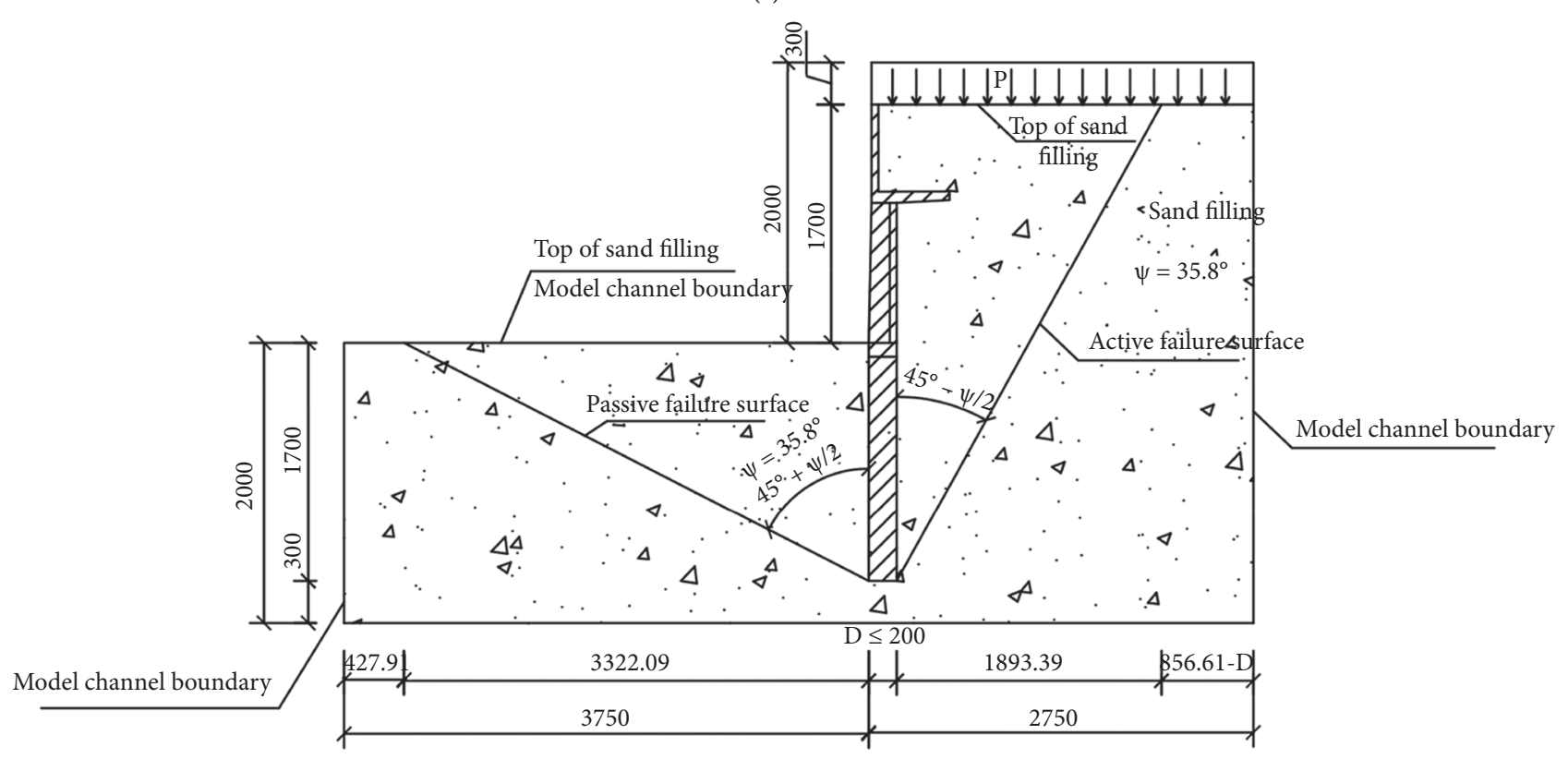

(b)

Figure 4: The dimension of model test box. (a) Planar graph. (b) Profile drawing (the unit of the dimension is mm).

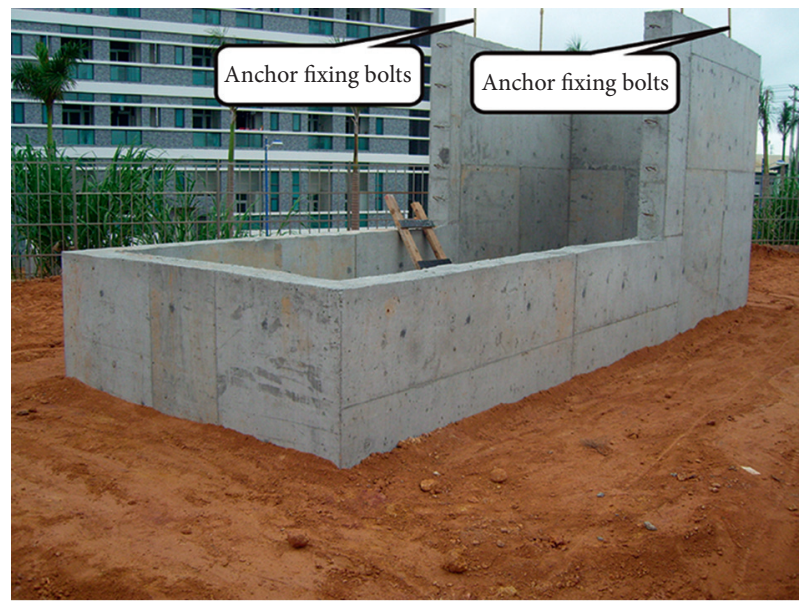

FIGURE 5: The real figure of model test box.

The front elevation drawing and profile drawing of the model structure are shown in Figure 6, while the real figure of the model structure is illustrated in Figure 7.

\subsection{Loading Equipment and Measurement System of the Test Model}

4.3.1. Loading Equipment of the Test Model. In the model tests, the air pressure load is used to simulate the load on the top of the wall. The loading equipment is shown in Figure 8. The test is undertaken among five levels from $10 \mathrm{kPa}$ to $50 \mathrm{kPa}$, with each level increasing by $10 \mathrm{kPa}$.

It is found that the air pressure load has two advantages: (1) When the load is unloaded, the load transmission is consistent and continuous without impact. (2) Its air pressure valve can be adjusted to maintain the load stability of each stage load. The magnitude of the change can be controlled within the range of $\pm 0.1 \mathrm{kPa}$.

4.3.2. Measurement System. The layout of the selected Earth pressure measuring equipment is shown in Figure 9.

The test data present the Earth pressure in the upper and lower walls. It is found that the measured Earth pressure before and after the pile foundation is the Earth pressure on the pile, not the average Earth pressure in the two piles. The 
TABLE 6: Characteristic parameters of retaining wall model structure.

\begin{tabular}{|c|c|c|c|c|c|c|}
\hline Components & $\begin{array}{l}\text { Required flexural } \\
\text { rigidity with unit } \\
\text { width }\left(\mathrm{N} \cdot \mathrm{m}^{2} / \mathrm{m}\right) \\
\text { (E) }\end{array}$ & $\begin{array}{l}\text { Calculation } \\
\text { width }(\mathrm{m})\end{array}$ & $\begin{array}{l}\text { Section } \\
\text { property of } \\
\text { materials }\end{array}$ & $\begin{array}{c}\text { Section } \\
\text { dimension of } \\
\text { materials }(\mathrm{mm})\end{array}$ & $\begin{array}{c}\text { Selected flexural } \\
\text { rigidity with unit } \\
\text { width }\left(\mathrm{N} \cdot \mathrm{m}^{2} / \mathrm{m}\right)(\mathrm{E})\end{array}$ & Remarks \\
\hline Pile & 6.795 & 0.6 & $\begin{array}{c}\text { Circular steel } \\
\text { pipe } \\
\end{array}$ & $159 \times 5$ & 7.205 & $\begin{array}{c}\text { Outer } \\
\text { diameter } \times \text { thickness } \\
\end{array}$ \\
\hline Rib pillar & 1.945 & 0.6 & $\begin{array}{l}\text { Square steel } \\
\text { pipe }\end{array}$ & $100 \times 2.5$ & 2.155 & $\begin{array}{c}\text { Outer } \\
\text { diameter } \times \text { thickness }\end{array}$ \\
\hline $\begin{array}{l}\text { Unloading } \\
\text { board }\end{array}$ & 1.225 & 0.6 & $\begin{array}{c}\text { Channel steel } \\
\text { and steel } \\
\text { plate }\end{array}$ & $\begin{array}{c}\text { Channel } \\
10+5 \text { mm steel } \\
\text { plate }\end{array}$ & 1.025 & $\begin{array}{c}\text { Small stiffness of channel } \\
\text { steel }\end{array}$ \\
\hline Top beam & 8.195 & - & $\begin{array}{l}\text { Square steel } \\
\text { pipe }\end{array}$ & $250 \times 5$ & 9.815 & - \\
\hline $\begin{array}{l}\text { Retaining } \\
\text { plate }\end{array}$ & 1.055 & 0.6 & $\begin{array}{c}\text { Wooden } \\
\text { board }\end{array}$ & Thickness: 36 & 1.155 & $\begin{array}{c}\text { Thickness: } 18 \mathrm{~mm} \text {; } \\
\text { overlapped wooden } \\
\text { board }\end{array}$ \\
\hline
\end{tabular}

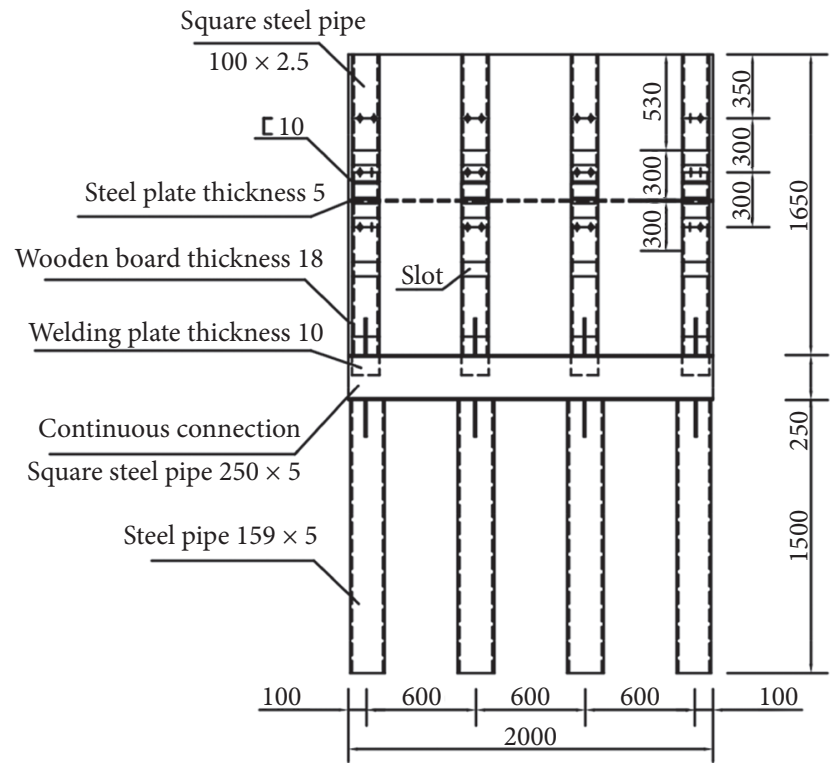

(a)

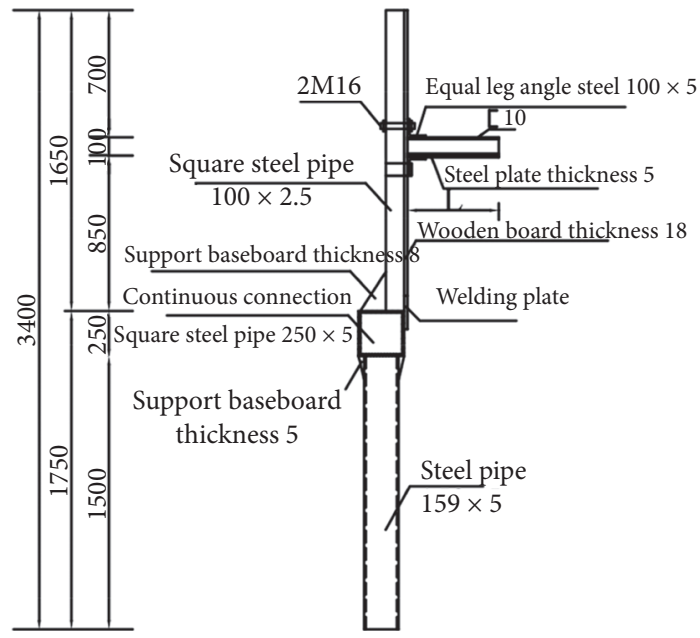

(b)

Figure 6: Front elevation drawing and profile drawing of model structure. (a) Front elevation drawing. (b) Profile drawing (the unit of the dimension: $\mathrm{mm}$ ).

conversion equation (3) is used to transform the measured value:

$$
P_{1}=P_{0} \frac{d}{b}
$$

In equation (3), $P_{0}$ is the measured Earth pressure before and after the pile, $P_{1}$ is the average Earth pressure in the two piles, $d$ is the pile diameter, and $b$ is the pile spacing.

The strain gauges are set up in the maximal internal force side of the pile and rib pillar in the retaining wall. The layouts of strain gauges are shown in Figure 10. After measuring the strain, the moment at each measurement point of the pile is calculated [37]:

$$
M_{x z}=\frac{E I_{\varepsilon y}}{(d / 2)} .
$$

In equation (4), $\varepsilon_{y}$ is the compressive (tensile) strain at the measurement point, $E$ is the elastic modulus of the pile, and $I$ is the moment of inertia of the cross section of the pile. The directions represented by $x, y$, and $z$ are shown in Figure 11.

By using the displacement measurement, the dial indicator with a range of $30 \mathrm{~mm}$ and an accuracy of $0.01 \mathrm{~mm}$ is selected. With the finite element method, the maximum displacement of the top of the retaining wall is $20.8 \mathrm{~mm}$ when it is in the most unsafe environment (without the unloading board). Assuming that the pile bottom is fixed, the maximum displacement at the 


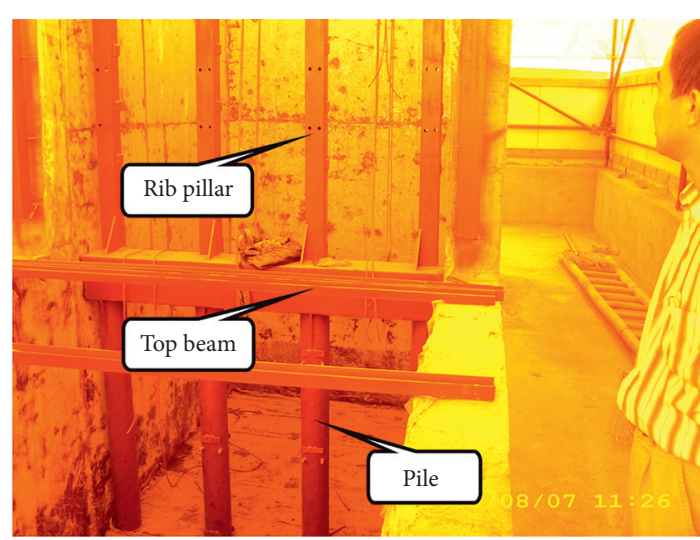

(a)

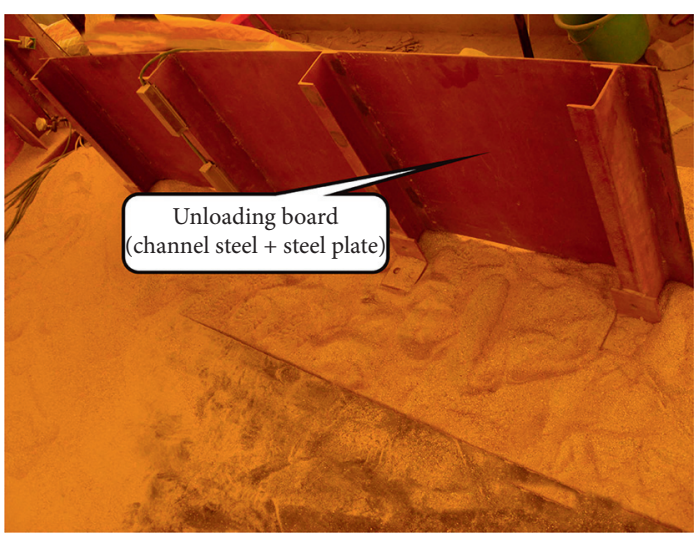

(b)

Figure 7: Real figure of model structure. (a) Real figure 1. (b) Real figure 2.

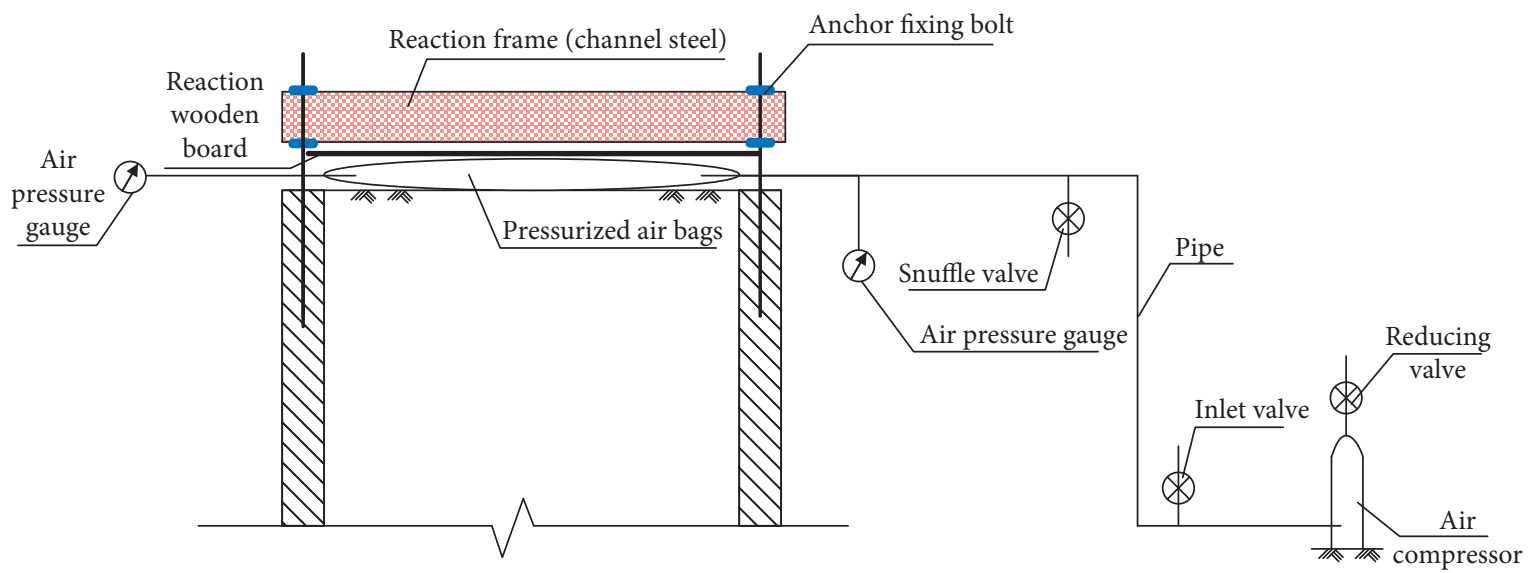

FIGURE 8: Schematic diagram of air pressure loading.

top of the retaining wall is calculated as $14.4 \mathrm{~mm}$. It is consistent within an environment with only one supported beam. Therefore, the meter of the dial gauge has a full scale of $30 \mathrm{~mm}$. The dial indicator is fixed by using the magnetic gauge seat and ensuring that the extendable rods are tipped on the square steel tubular. It is found that the retaining wall is deflected with the increasing thickness of the sand layer. Moreover, the dial indicator can be used to measure the displacement of the retaining wall simultaneously. At the time of testing, there are ten horizontal displacement measuring points on the rib pillar. Ten dial indicators are installed to measure the horizontal displacement of the retaining wall. The layout and number of displacement measurement points are shown in Figure 12.

4.3.3. Data Acquisition and Processing System. Earth pressure and strain data acquisition are equipped with the automatic acquisition of artificial guards. Moreover, the automatic collection box is equipped with an accumulator and a module that automatically controls the measurement of the sensor within a specified time. The measurement results are first saved in the vibrating wire sensor (as shown in Figure 13), which is connected to an external data collection box. Then, the automatic dynamic monitoring of the network is implemented. Finally, the data acquisition system software is used to aggregate data collected in various modes into a database and further display and process task switching. Measurement data is saved in an Excel spreadsheet for subsequent analysis and processing. The schematic diagram of data transmission, collection, and processing switching work is shown in Figure 14.

\section{Test Scheme}

A total of 28 grouping model tests are conducted: one group test without the unloading board, 18 group comparison tests without external loading, and 9 group external load comparison tests. The combination of tests is shown in Table 7, and the parameters are shown in Figure 15.

A retaining wall model test without the unloading board is performed firstly. The test has four purposes. First, it is used to verify the validity and reliability of the test instrument. Second, it is known that the structure of the retaining wall without the unloading board is relatively simple. Thus, the accuracy of the measurement data of the retaining wall model is verified by comparing them with the results from other theories. Third, in comparison with the results of the test model of the unloading board retaining wall, the unloading effect of the unloading board is analyzed; that is, 


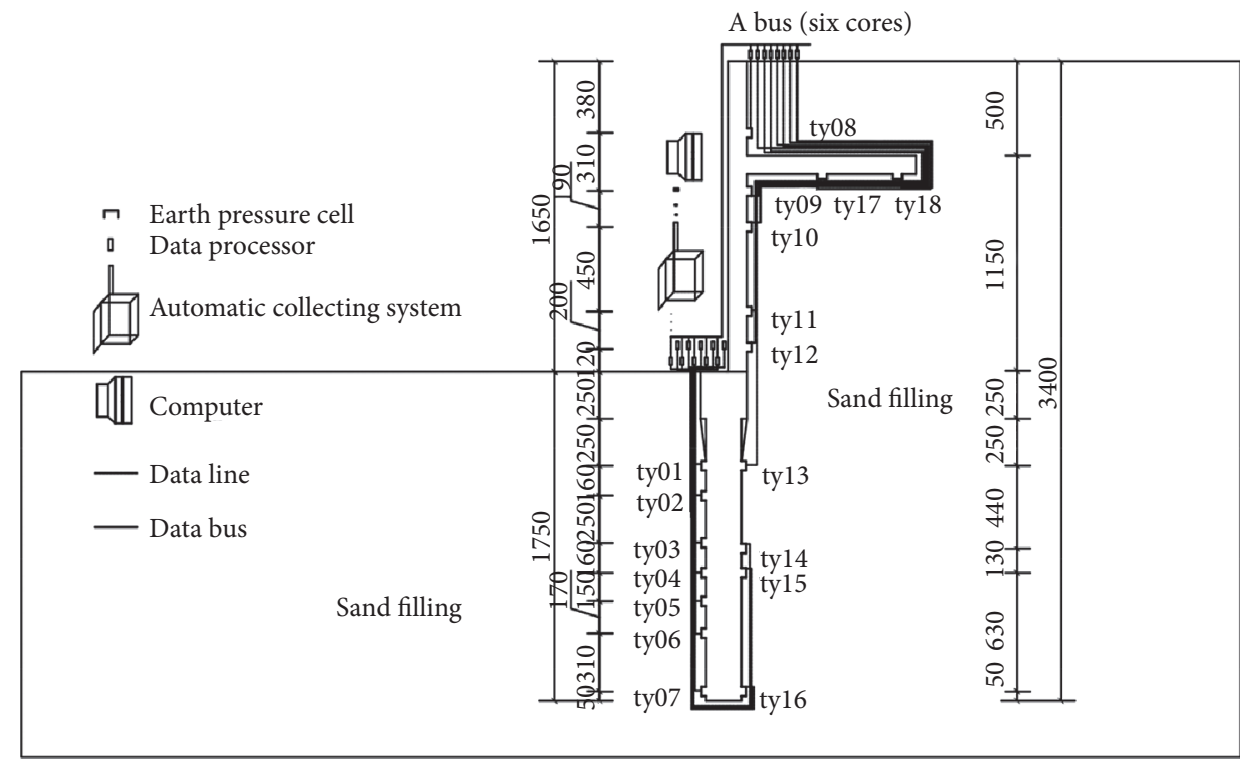

Statements

1. When the length of plate changes, the layout of earth pressure cell position is not affected on some plates (ty17, ty18).

2. When the plate position changes, earth pressure cell position change didn't affect the upper, lower and pile bottom unloading board.

3. The dimension unit in the figure is $\mathrm{mm}$.

FIgURE 9: The layout of Earth pressure cell.
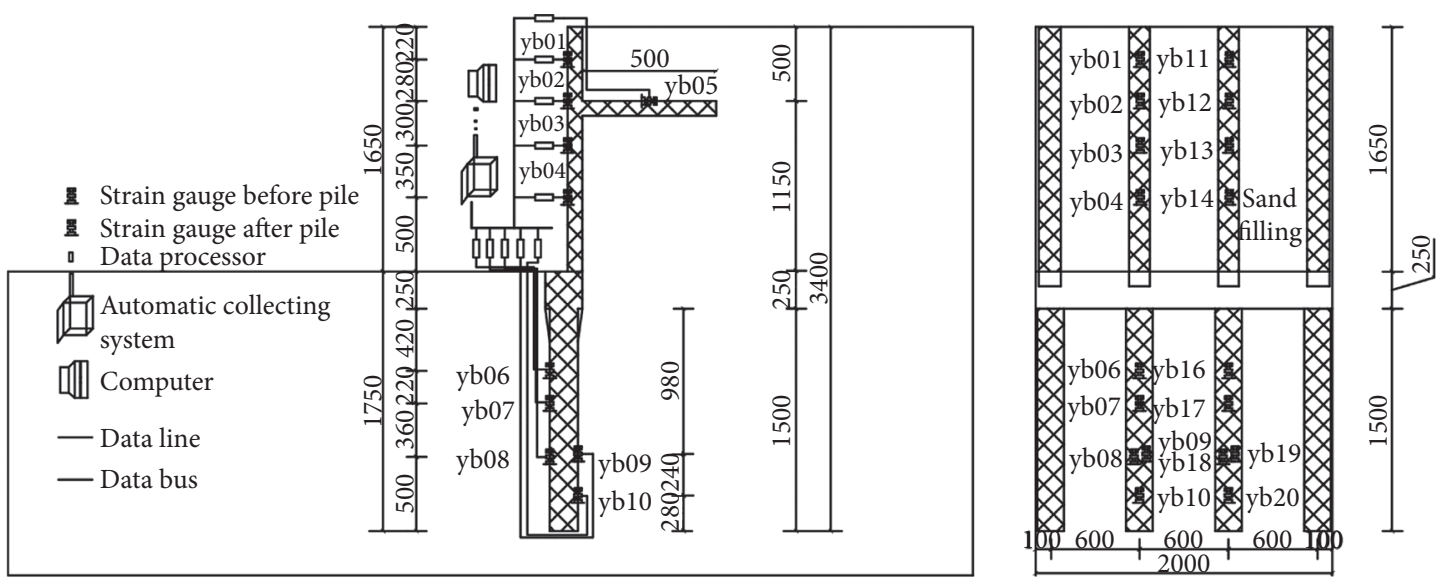

Statements

1. Strain gauge position layout when plate length changed didn't affect the plate (yb05).

2. Strain gauge position change when the plate position changed didn't affect the upper, lower and pile bottom unloading board.

3. The dimension unit in the figure is $\mathrm{mm}$.

Figure 10: Strain gauge layout.

the unloading effect is established. The effect of the unloading board has mechanical and deformation characteristics. The retaining wall is analyzed at the end of the test. Fourth, by analyzing all the issues involved in the test, the experience of conducting the test is reflected and summarized. Based upon these, the subsequent tests are completed. The test process is shown in Figure 16.

\section{Test Results and Discussion}

6.1. Distribution of Earth Pressure. The Earth pressure behind the retaining wall and prepile resistance force without the unloading board25 are shown in Figures 17 and 18. Figure 17 shows that there is a linear increasing tendency with the depth in the measured Earth pressure behind the 


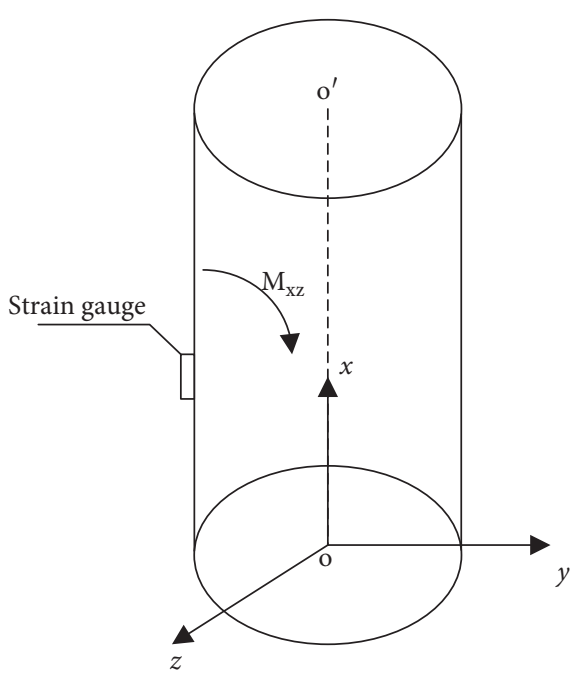

Figure 11: The directions represented by $x, y$, and $z$.

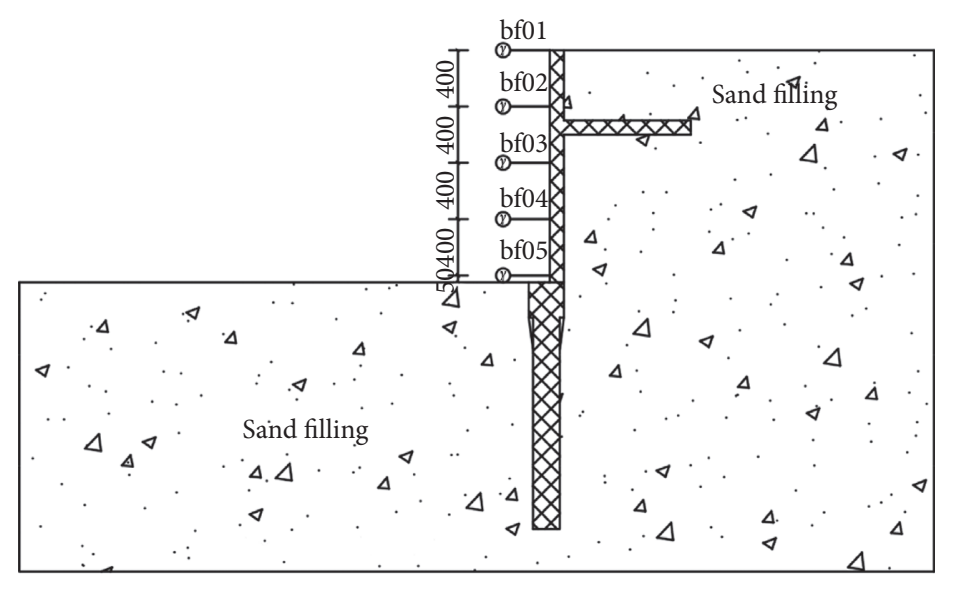

$\odot$ - Dial indicator

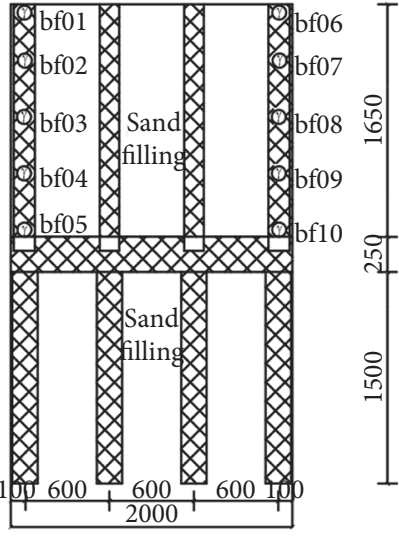

(b)

Figure 12: External displacement measurement point layout of retaining wall (unit: $\mathrm{mm}$ ). (a) Side view drawing. (b) Front elevation drawing.

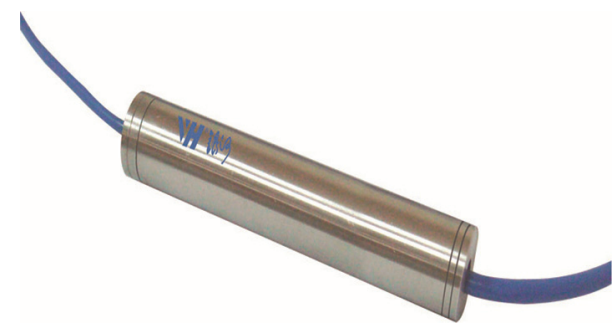

Figure 13: The vibrating wire sensor.

retaining wall. Moreover, the measured Earth pressure behind the wall lies between Rankine Earth pressure and Earth pressure at rest, showing that the soil behind the wall is kept in the progressive active failure state. The measured Earth pressure at the bottom of retaining wall is 1.33 times the calculation value by Rankine theory and 0.82 times Earth pressure at rest.
Figure 18 shows that the measured prepile resistance force tends to increase first and then decrease afterwards with the depth. It is found that the measured prepile resistance force at the bottom of retaining wall is close to zero (this is much less than theoretical calculation value by Rankine's theory). The measured prepile resistance force of the upper wall (above $0.6 \mathrm{~m}$ depth) is close to Coulomb's Earth pressure. This indicates that the upper wall remains in a progressive passive limit state. The measured prepile resistance force of the lower wall (below $0.6 \mathrm{~m}$ depth) is found to be much less than the calculation value by Rankine Earth pressure. The measured prepile resistance force is close to the calculation value by $\mathrm{m}$ method in "JGJ 120-2012, J 1412-2012: Technical Specifications for Retaining and Protection of Building Foundation Excavations" (Ministry of Housing and Urban-Rural Development of the People's Republic of China, 2010). It indicates that the prepile resistance force can be approximated by using the m method. 


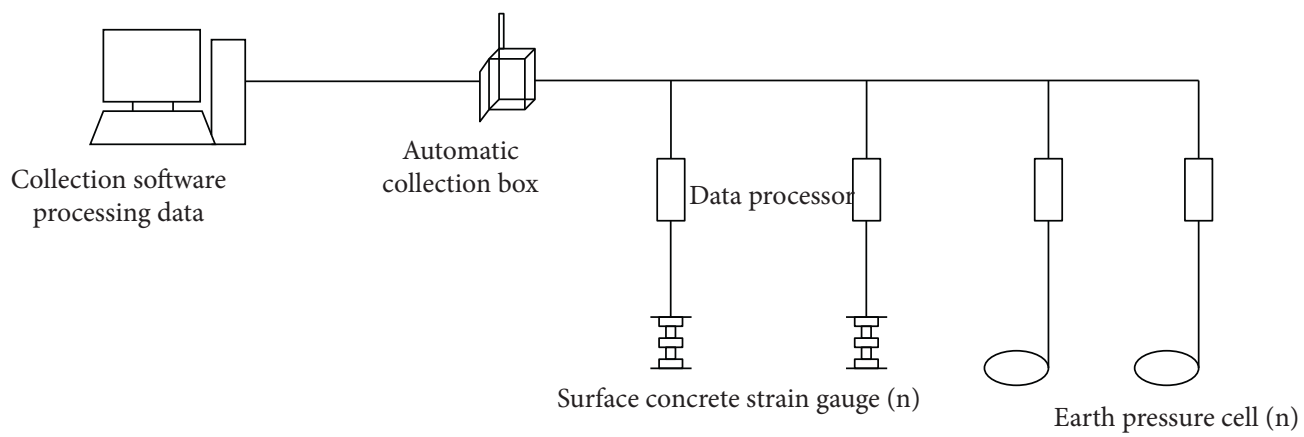

FIGURE 14: Schematic diagram of data transmission, collection, and processing switching work.

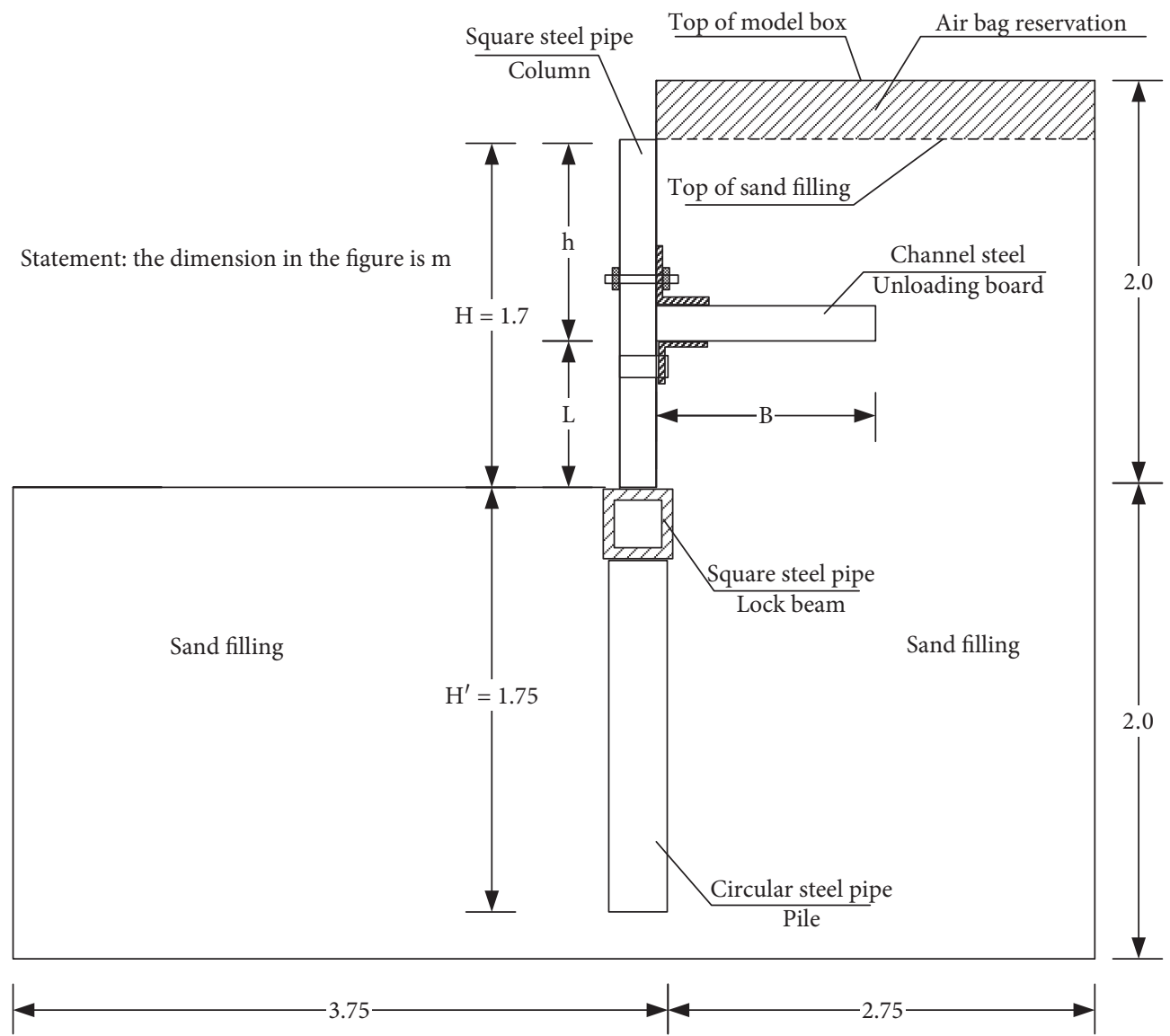

FIgURE 15: Parameters figure for the combination of tests.

The present study found that the Earth pressure distribution measured before and behind the wall has a certain regularity. The reason is shown in Figure 19. In Figure 19, It is found that there is a turning point on the position of the bottom of retaining wall's pile foundation, that is, a zerodisplacement point. With the development of deformation with the retaining wall structure, the Earth pressure above the zero-displacement point behind the pile develops from the static Earth pressure to the active Earth pressure, showing a gradual active limit state. Moreover, the Earth pressure under the zero-displacement point behind the pile develops from static Earth pressure to passive Earth pressure. Therefore, the
Earth pressure measured by the Earth pressure cell $\mathrm{H}$ is the passive Earth pressure, and the Earth pressure measured by the Earth pressure cell $\mathrm{H}$ is larger than the calculated value by the Rankine theory. The Earth pressure above the zero-displacement point before the pile develops from static Earth pressure to passive Earth pressure, showing a progressively passive limit state. The Earth pressure under the zero-displacement point before the pile changes from static Earth pressure to active Earth pressure. In addition, during the process of the turning of the pile, it is found that the deformation of the right sand at the bottom of the pile is small, or the deformation of the right sand cannot grasp the turning 
TABLE 7: Combination of tests.

\begin{tabular}{|c|c|c|c|c|c|c|}
\hline Grouping number & $\mathrm{H}(\mathrm{m})$ & $\mathrm{B}(\mathrm{m})$ & $\mathrm{H}(\mathrm{m})$ & $\mathrm{B} / \mathrm{H}$ & $\mathrm{h} / \mathrm{H}$ & Load at wall top $q(\mathrm{kPa})$ \\
\hline 1 & 1.70 & 0 & 1.70 & 0 & - & 0 \\
\hline 2 & 1.70 & 0.4 & 0.6 & 0.24 & 0.35 & 0 \\
\hline 3 & 1.70 & 0.4 & 0.9 & 0.24 & 0.53 & 0 \\
\hline 4 & 1.70 & 0.4 & 1.2 & 0.24 & 0.70 & 0 \\
\hline 5 & 1.70 & 0.5 & 0.6 & 0.30 & 0.35 & 0 \\
\hline 6 & 1.70 & 0.5 & 0.9 & 0.30 & 0.53 & 0 \\
\hline 7 & 1.70 & 0.5 & 1.2 & 0.30 & 0.70 & 0 \\
\hline 8 & 1.70 & 0.6 & 0.6 & 0.35 & 0.35 & 0 \\
\hline 9 & 1.70 & 0.6 & 0.9 & 0.35 & 0.53 & 0 \\
\hline 10 & 1.70 & 0.6 & 1.2 & 0.35 & 0.70 & 0 \\
\hline 11 & 1.70 & 0.8 & 0.6 & 0.47 & 0.35 & 0 \\
\hline 12 & 1.70 & 0.8 & 0.9 & 0.47 & 0.53 & 0 \\
\hline 13 & 1.70 & 0.8 & 1.2 & 0.47 & 0.70 & 0 \\
\hline 14 & 1.70 & 1.0 & 0.6 & 0.59 & 0.35 & 0 \\
\hline 15 & 1.70 & 1.0 & 0.9 & 0.59 & 0.53 & 0 \\
\hline 16 & 1.70 & 1.0 & 1.2 & 0.59 & 0.70 & 0 \\
\hline 17 & 1.70 & 1.2 & 0.6 & 0.70 & 0.35 & 0 \\
\hline 18 & 1.70 & 1.2 & 0.9 & 0.70 & 0.53 & 0 \\
\hline 19 & 1.70 & 1.2 & 1.2 & 0.70 & 0.70 & 0 \\
\hline 20 & 1.70 & 0.4 & 0.6 & 0.24 & 0.35 & $10,20,30,40,50$ \\
\hline 21 & 1.70 & 0.4 & 0.9 & 0.24 & 0.53 & $10,20,30,40,50$ \\
\hline 22 & 1.70 & 0.4 & 1.2 & 0.24 & 0.70 & $10,20,30,40,50$ \\
\hline 23 & 1.70 & 0.6 & 0.6 & 0.35 & 0.35 & $10,20,30,40,50$ \\
\hline 24 & 1.70 & 0.6 & 0.9 & 0.35 & 0.53 & $10,20,30,40,50$ \\
\hline 25 & 1.70 & 0.6 & 1.2 & 0.35 & 0.70 & $10,20,30,40,50$ \\
\hline 26 & 1.70 & 1.0 & 0.6 & 0.59 & 0.35 & $10,20,30,40,50$ \\
\hline 27 & 1.70 & 1.0 & 0.9 & 0.59 & 0.53 & $10,20,30,40,50$ \\
\hline 28 & 1.70 & 1.0 & 1.2 & 0.59 & 0.70 & $10,20,30,40,50$ \\
\hline
\end{tabular}

Notes: the meanings of $\mathrm{B}$ and $h$ in the table are shown in Figure 15.

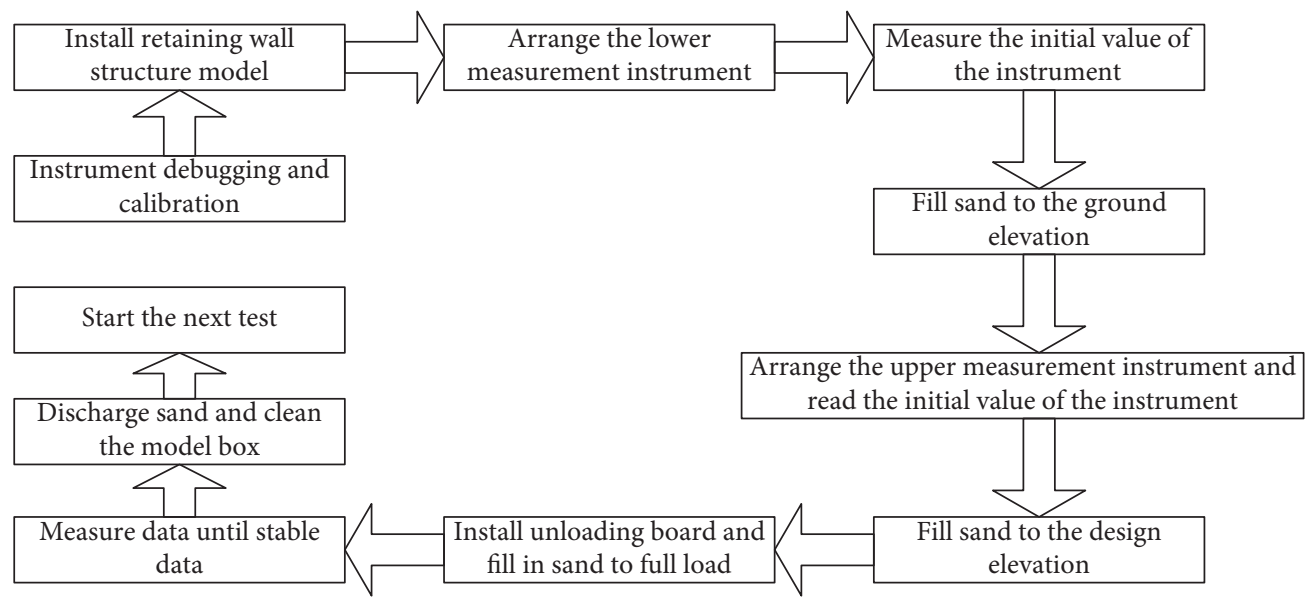

FIgURE 16: Flow chart of test.

deformation of the pile. In other words, there is a loose contact between the pile and the sand, resulting in a small measurement of the Earth pressure unit N.

6.2. Internal Force Distribution of the Retaining Wall. The internal force change of the retaining wall is largely reflected in the bending moment of the retaining wall structure. The bending moment distribution curve of the retaining wall is shown in Figure 20. In Figure 20, it is found that the measured bending moment value approximates the calculated value by the $\mathrm{m}$ method and is larger than the bending moment value calculated by the finite difference method. During the model test, the sand is layered 6 times in total. It is found that when the sand surface is flat, the external load generated by the human body's own weight increases, causing the measured strain value to be greater than the strain value calculated by the finite difference method. Therefore, the measured moment value is found to be greater 


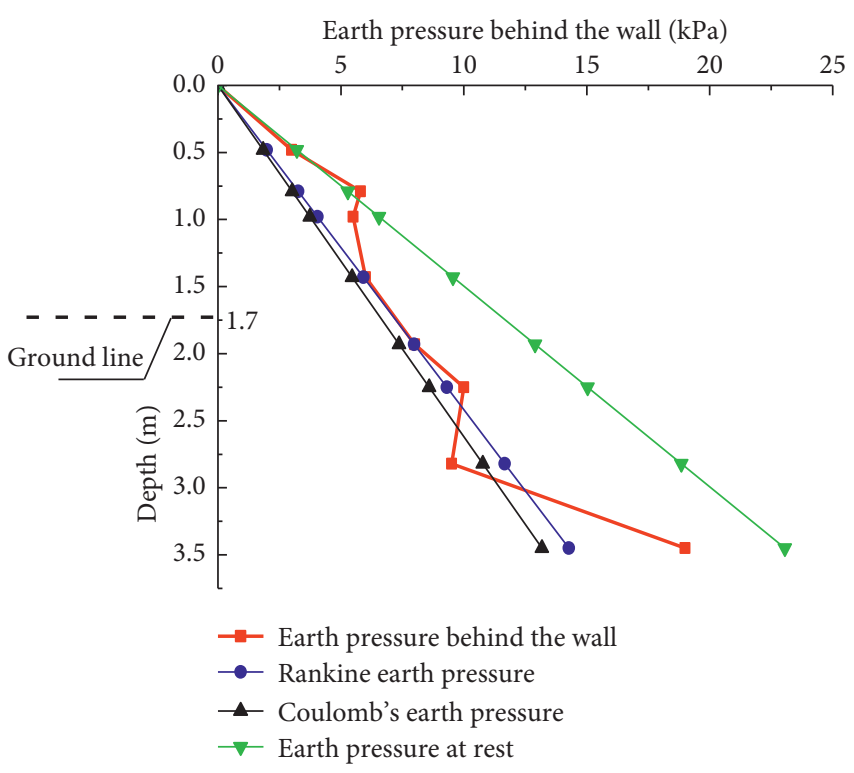

FIGURE 17: Earth pressure behind the retaining wall without the unloading board.

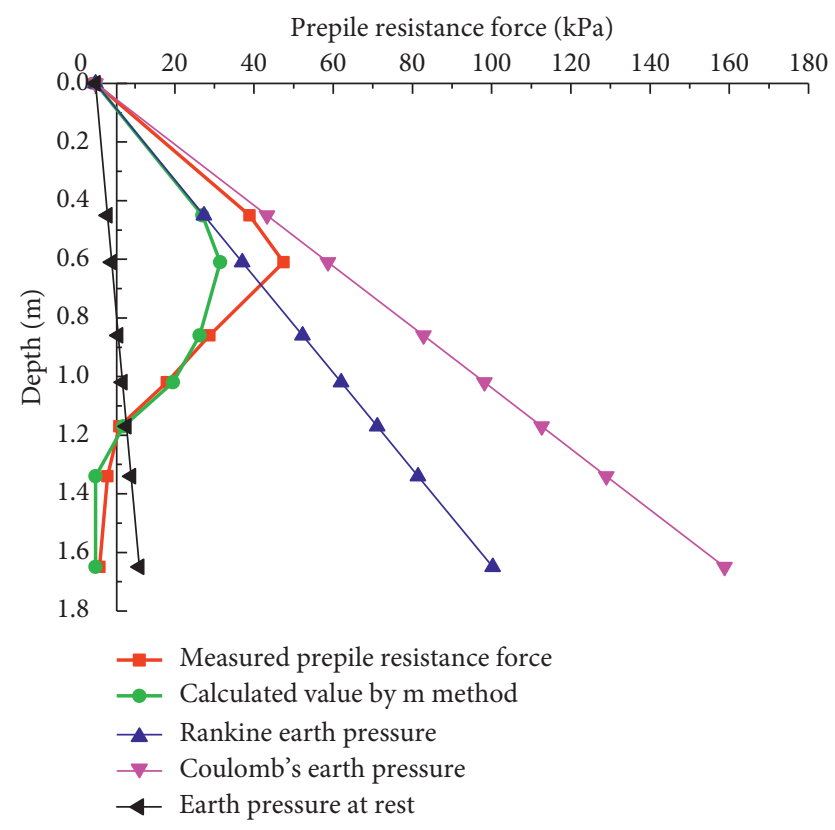

FIGURE 18: The prepile resistance force of the retaining wall without the unloading board.

than the moment value calculated by the finite difference method.

6.3. Deformation of the Retaining Wall's Rib Pillars. Figure 21 shows that the deformation measurements are made on the two rib pillars of the retaining wall (pillar A is on the right side, and pillar B is on the left side). It is found that the field measurement conditions limit the measurement, resulting in the fact that only the measured values of

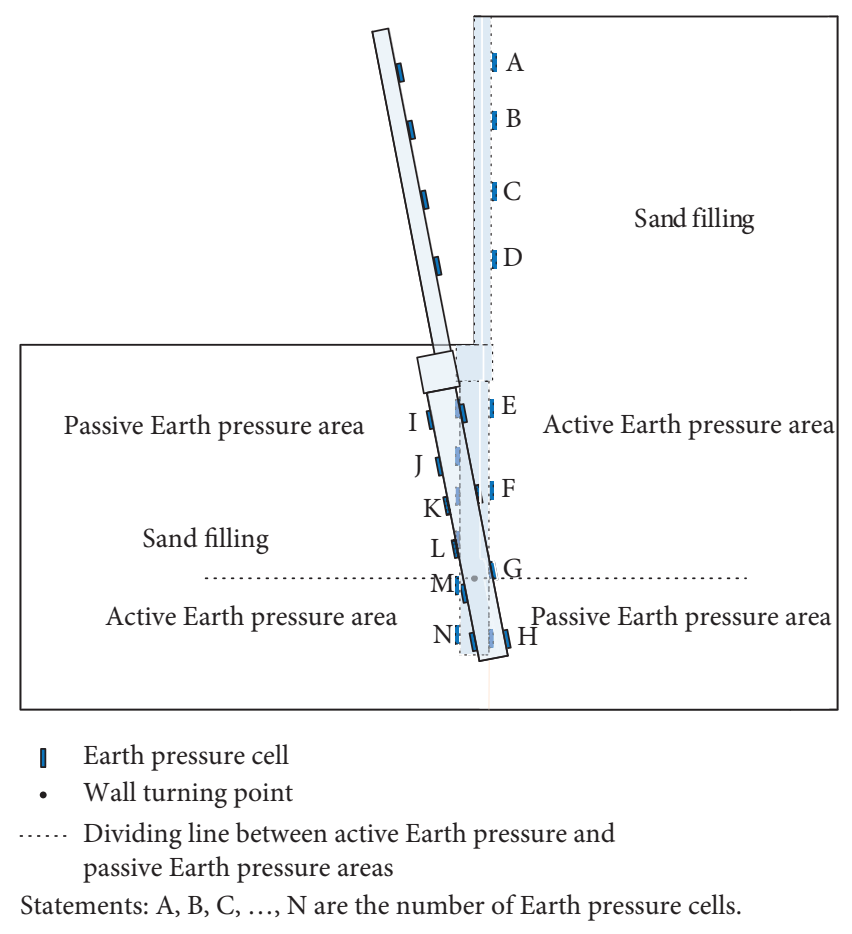

FIGURE 19: Interpretation drawing of Earth pressure distribution of the retaining wall.

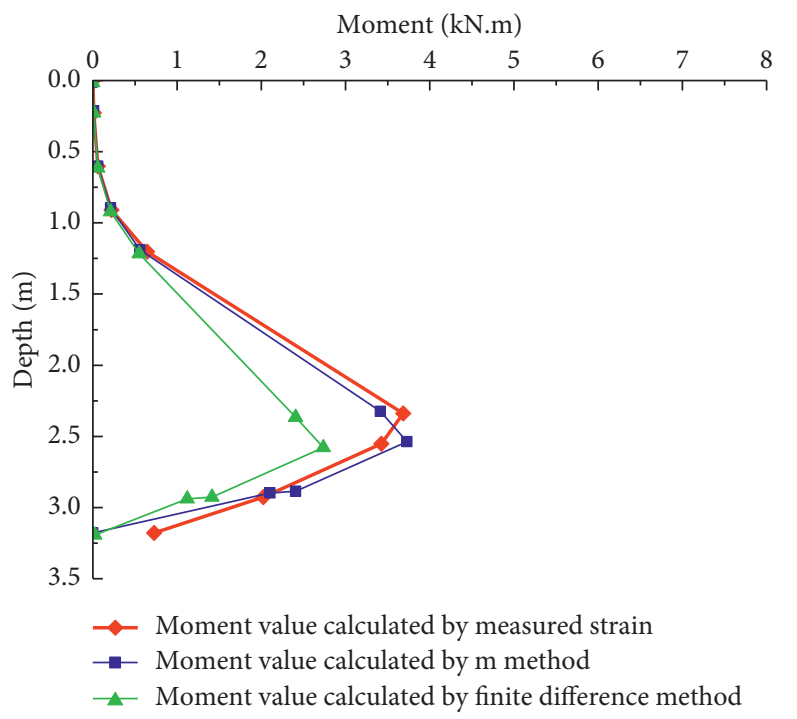

FIgURE 20: Bending moment distribution curve of the retaining wall.

the left and right rib pillars are measured. The amount of deformation of the rib pillars on the retaining wall and the calculated value of the finite difference method are shown in Figure 22.

Figure 22 presents the following important findings:

(1) The entire retaining wall structure is externally inclined. The ratio between the displacement of the retaining wall's upper rib pillar at the top $\Delta \mathrm{x}$ and rib pillar height $\mathrm{H}$ is $25.12 \mathrm{~mm} / 1650 \mathrm{~mm}=1.52 \%$. This value is greater than the value of sheet pile retaining 


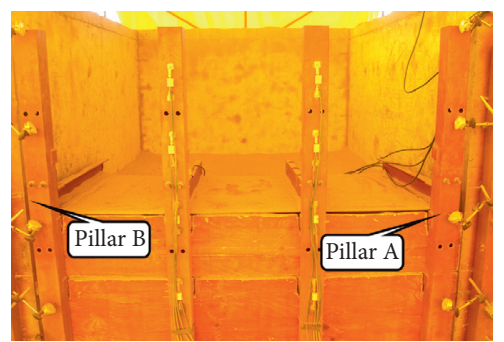

Figure 21: Position of pillar A and pillar B and embedded line diagram of the instrument.

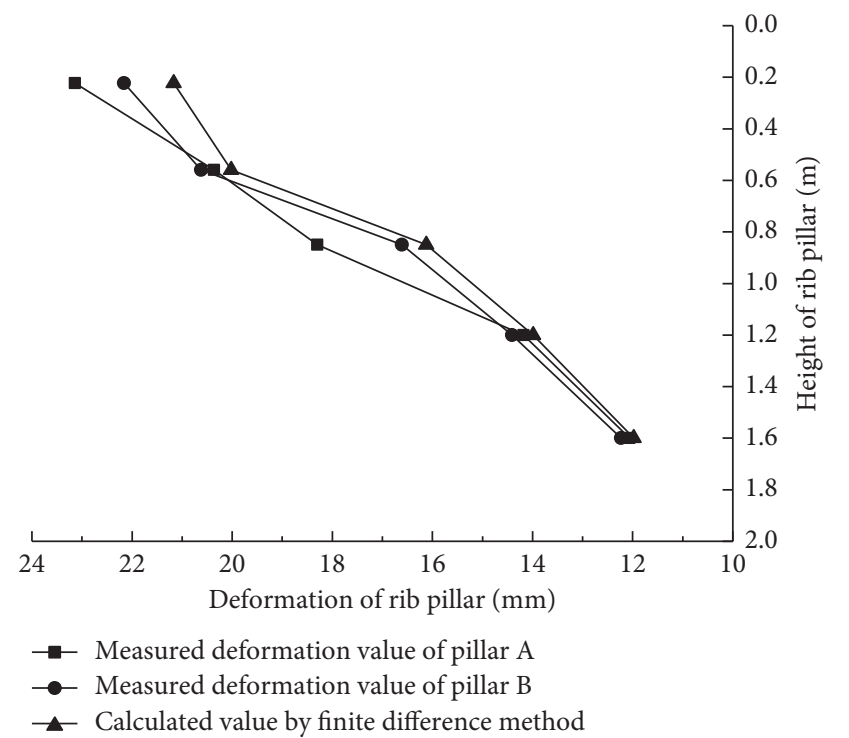

Figure 22: The deformation curve of the retaining wall's upper rib pillar.

wall's displacement; however, it is less than $1 \%$ of retaining wall's cantilever length required by "TB 10025-2006, J 127-2006: Code for Design on Retaining Structures of Railway Subgrade" (Ministry of Railways of the People's Republic of China, 2006), namely, $\Delta \mathrm{x} / \mathrm{H} \leq 1.0 \%$. This results in a failed retaining wall. In summary, this finding indicates that when the upper part of the retaining wall has no unloading board, the entire retaining wall structure fails.

(2) The deformation of pillar A is slightly larger than that of pillar $\mathrm{B}$, which indicates that numerous buried instrument wires below pillar A force the sand filling of pillar A to be loose. In addition, it is found that the external displacement of pillar $\mathrm{A}$ is greater than the displacement of pillar B.

(3) Owing to the 6 times (in total) of layers of sand in the model test, the measured deformation in the retaining wall's upper rib pillar is greater than the calculated results using the finite difference method. The sum of the incremental results of the six times monitoring is considered as the total displacement (the external load has to be generated by the body's self-weight each time, and the sand surface is flattened). This total displacement is then calculated by using the finite difference method from the start to the equilibrium increment for accurate measurement. Therefore, it is found that the displacement is greater than the displacement calculated by the finite difference method.

\section{Conclusions}

Based on the studies presented in this study, the credibility and validity of the self-made model of the retaining wall, the test instrument, and the test data are verified, and the following five contributions to the field can be extracted:

(1) The measured Earth pressure behind the sheet pile wall with relieving platform without the unloading board has a strong linear correlation with its depth. This value lies between the values of Rankine Earth pressure and Earth pressure at rest and the soil behind the wall remains in a progressive active failure state.

(2) The measured prepile resistance force of the upper wall (above $0.6 \mathrm{~m}$ depth) is close to the Coulomb's Earth pressure and that of the lower wall (below $0.6 \mathrm{~m}$ depth) is much less than the calculation value by Rankine Earth pressure. Moreover, the measured prepile resistance force can be used for approximate calculation by the method.

(3) There is a zero-displacement point on the pile bottom of the retaining wall, with the development of deformation with the retaining wall structure; the front and back zones of the pile are divided into the passive Earth pressure zone and active Earth pressure zone by the zero-displacement point.

(4) The measured moment value of the sheet pile wall with relieving platform without the unloading board is close to the value calculated by the m method, and the $\mathrm{m}$ method can be used for the approximate calculation.

(5) The ratio between the displacement of the upper rib pillars in the retaining wall and its height is greater than the corresponding standard requirement, indicating that the retaining wall without the unloading board has failed. Thus, the unloading board should be installed to exert the unloading effect and improve the stress and deformation characteristics of the retaining wall.

\section{Nomenclature}

E: $\quad$ Elastic modulus of the material in the retaining wall structure

$\mu$ : $\quad$ Poisson's ratio of the material in the retaining wall structure

$\rho: \quad$ Natural density of the material in the retaining wall structure

$c$ : $\quad$ Cohesive force of soil 


\begin{tabular}{|c|c|}
\hline$\varphi:$ & Internal friction angle of soil \\
\hline$\rho_{\mathrm{d}}:$ & Dry density of the medium-coarse sand \\
\hline$\lambda:$ & $\begin{array}{l}\text { Similarity coefficient of the same physical } \\
\text { quantity in the prototype and model of the } \\
\text { retaining wall }\end{array}$ \\
\hline$x_{\mathrm{p}}:$ & $\begin{array}{l}\text { Any physical quantity in the prototype of the } \\
\text { retaining wall }\end{array}$ \\
\hline$x_{\mathrm{m}}:$ & $\begin{array}{l}\text { Any physical quantity in the model of the } \\
\text { retaining wall }\end{array}$ \\
\hline$\lambda_{\varepsilon}:$ & Similarity coefficient of the strain of the material \\
\hline$\lambda \rho:$ & $\begin{array}{l}\text { Similarity coefficient of the natural density of the } \\
\text { material }\end{array}$ \\
\hline$\lambda \gamma:$ & $\begin{array}{l}\text { Similarity coefficient of material specific gravity or } \\
\text { bulk density }\end{array}$ \\
\hline$\lambda \varphi$ : & $\begin{array}{l}\text { Similarity coefficient of the internal friction angle } \\
\text { of the material }\end{array}$ \\
\hline$\varepsilon:$ & Strain of the structure \\
\hline$q:$ & Area force at wall top \\
\hline$\sigma:$ & Stress of the structure \\
\hline s: & Displacement of the structure \\
\hline EI: & Unit flexural stiffness of the structure \\
\hline $\mathrm{Cu}:$ & Coefficient of uniformity of the soil \\
\hline Cc: & Coefficient of curvature of the soil \\
\hline$(\mathrm{EI})_{\mathrm{p}}:$ & Actual stiffness of the prototype structure \\
\hline$(\mathrm{EI})_{\mathrm{m}}:$ & Actual stiffness of the model structure \\
\hline$(\mathrm{EI})_{\mathrm{p}}^{\prime}:$ & Stiffness of unit width in the prototype structure \\
\hline$(\mathrm{EI})_{\mathrm{m}}^{\mathrm{r}}$ : & Stiffness of unit width in the model structure \\
\hline$\rho_{\text {Soil }}$ & Natural density of the soil and sand \\
\hline$\rho_{\text {Sand }}:$ & \\
\hline$\rho_{\text {Concrete: }}$ & Natural density of the concrete material \\
\hline$\rho_{\text {Steel }}:$ & Natural density of the steel material \\
\hline $\mathrm{E}_{\text {board }}$ : & $\begin{array}{l}\text { Elastic modulus of the wooden board in the model } \\
\text { structure }\end{array}$ \\
\hline$\rho_{\text {board }}:$ & $\begin{array}{l}\text { Natural density of the wooden board in the model } \\
\text { structure }\end{array}$ \\
\hline $\mathrm{P}_{0}$ : & Measured Earth pressure before and after the pile \\
\hline $\mathrm{P}_{1}$ : & Average Earth pressure within two piles \\
\hline $\mathrm{d}:$ & Pile diameter \\
\hline b: & Pile spacing \\
\hline M: & Moment at each measurement point of the pile \\
\hline$\varepsilon_{\mathrm{y}}:$ & $\begin{array}{l}\text { Compressive (tensile) strain at the measurement } \\
\text { point }\end{array}$ \\
\hline I: & Moment of inertia of cross section of the pile \\
\hline $\mathrm{H}:$ & Height of the retaining wall or rib pillar \\
\hline h: & Buried depth of the unloading board \\
\hline B: & Width of the unloading board \\
\hline$\triangle \mathrm{x}:$ & $\begin{array}{l}\text { Displacement of the retaining wall's upper rib } \\
\text { pillar at the top. }\end{array}$ \\
\hline
\end{tabular}

\section{Data Availability}

The data and figures used to support the findings of this study are included within the article.

\section{Conflicts of Interest}

The authors declare that they have no conflicts of interest.

\section{Acknowledgments}

This work was supported by the National Natural Science Foundation of China (no. 51678017), the National Key R\&D Program of China (no. 2018YFD1100902-1), and the Key Scientific Research Projects of Henan Provincial Colleges and Universities (no. 17A560002) in China. The authors would like to express their gratitude to these financial supports.

\section{References}

[1] G. M. Sabnis, H. G. Harris, R. N. White et al., "Structural modeling and experimental techniques," Journal of Dynamic Systems, Measurement, and Control, vol. 105, no. 7, Article ID 307, 1983.

[2] J. J. Yang, Similarity Theory and Structural Modeling Experiment, Wuhan University of Technology Press, Wuhan, China, 2005.

[3] J. K. Young, S. J. Hyuk, and J. L. Yong, "Behaviour analysis of reinforced soil retaining wall according to laboratory scale test," Applied Sciences, vol. 10, no. 3, Article ID 901, 2020.

[4] K. S. Wong, B. B. Broms, and B. Chandrasekaran, "Failure modes at model tests of a geotextile reinforced wall," Geotextiles and Geomembranes, vol. 13, no. 6-7, pp. 475-493, 1994.

[5] C. S. Yoo, H. S. Jung, S. S. Jeon et al., "Failure mechanism of geosynthetic reinforced segmental retaining wall in tiered configuration using reduced-scale model tests," Journal of the Korean Geotechnical Society, vol. 21, pp. 65-77, 2005.

[6] R. H. Chen and Y. M. Chiu, "Model tests of geocell retaining structures," Geotextiles and Geomembranes, vol. 26, no. 1, pp. 56-70, 2008.

[7] C. Z. Xiao, Q. Q. Chen, and J. Han, "Experimental study of performance of geogrid-reinforced retaining wall subjected to load from strip foundation at the top surface of wall," Rock and Soil Mechanics, vol. 34, no. 6, pp. 1586-1592, 2013.

[8] J. S. Ki, W. H. Rew, S. K. Kim, and B. S. Chun, "A behavior of curve section of reinforced retaining wall by model test," Journal of The Korean Society of Civil Engineers, vol. 32, no. 6C, pp. 249-257, 2012.

[9] L. H. Li, C. D. Yu, H. L. Xiao et al., "Experimental study on the reinforced fly ash and sand retaining wall under static load," Construction and Building Materials, vol. 248, no. 10, Article ID 118678, 2020.

[10] H. Wang, G. Yang, Z. Wang, and W. Liu, "Static structural behavior of geogrid reinforced soil retaining walls with a deformation buffer zone," Geotextiles and Geomembranes, vol. 48, no. 3, pp. 374-379, 2020.

[11] D.-U. Jeong, J.-C. Im, J.-W. Yoo, M.-S. Seo, Y.-M. Koo, and S.-J. Kim, "An experimental study on the inclined earth retaining structure in clay," Journal of the Korean Geotechnical Society, vol. 29, no. 6, pp. 63-75, 2013.

[12] M.-S. Seo, J.-C. Im, D.-U. Jeong, J.-W. Yoo, Y.-M. Koo, and G.-H. Kim, "An experimental study on the stability of inclined earth retaining," Journal of the Korean Geotechnical Society, vol. 28, no. 12, pp. 99-110, 2012.

[13] J.-W. Yoo, J.-C. Im, S.-P. Hwang, C.-Y. Kim, J.-H. Choi, and H.-S. Kim, "An experimental study on the stability of assembled earth retaining wall in sandy ground," Journal of the Korean Geotechnical Society, vol. 32, no. 2, pp. 43-52, 2016.

[14] H. Kim, J.-C. Im, J. Choi, and M. Seo, "Mechanical effects of back supporting beam of assembled earth retaining wall on 
field model tests results," Journal of the Korean Society of Civil Engineers, vol. 37, no. 2, pp. 343-355, 2017.

[15] S. Kim, D. E. Lee, Y. Kim et al., "Development and application of precast concrete double wall system to improve productivity of retaining wall construction," Sustainability, vol. 12, no. 8, Article ID 3454, 2020.

[16] F. A. Salman, M. Y. Fattah, S. M. Shirazi et al., "Comparative study on earth pressure distribution behind retaining walls subjected to line loads," Scientific Research and Essays, vol. 6, pp. 2228-2244, 2011.

[17] F. A. Salman, M. Y. Fattah, and D. K. Sabre, "Long term behaviour of a retaining wall resting on clayey soil," International Journal of the Physical Sciences, vol. 6, pp. 730-745, 2011.

[18] W.-K. Yoo, B.-I. Kim, I.-J. Moon, and Y.-S. Park, "Comparison of the lateral earth pressure on the retaining wall with the relieving platform by model test and numerical analysis," Journal of the Korea Academia-Industrial Cooperation Society, vol. 13, no. 5, pp. 2382-2389, 2012.

[19] I.-J. Moon, B.-I. Kim, W.-K. Yoo, and Y.-S. Park, "Model tests for measurement of lateral earth pressure on retaining wall with the relieving platform using jumoonjin sand," Journal of the Korea Academia-Industrial Cooperation Society, vol. 14, no. 11, pp. 5923-5929, 2013.

[20] H. F. Shehata, "Use of retaining walls with relief shelves as an economic solution," in Proceedings of the Advances in $\mathrm{Nu}$ merical and Experimental Analysis of Transportation Geomaterials and Geosystems for Sustainable Infrastructure, Fourth Geo-China International Conference, ASCE, Shandong, China, pp. 82-90, July 2016.

[21] I. Kim, W. K. Yoo, M. R. Yang et al., "Model test study on the earth pressure of the retaining wall with the relieving platform," Journal of Korean Society of Civil Engineers, vol. 32, no. 1, pp. 27-35, 2012.

[22] A. Eslami and J. Bazaz, "Study of bored pile retaining wall using physical modeling," International Journal Civil Environmental Structure Construction Architecture Engineering, vol. 9, no. 1, pp. 15-18, 2015.

[23] W. R. Azzam and A. Z. Elwakil, "Performance of axially loaded-piled retaining wall: experimental and numerical analysis," International Journal of Geomechanics, vol. 17, no. 2, Article ID 04016049, 2017.

[24] Y. C. Liu, "The model test research on pile-supported relieving retaining wall," M.S. Thesis, China Academy of Railway Sciences, Beijing, China, 2010.

[25] R. H. Hu, G. N. Liu, and X. H. Pan, "Parameters determination of unloading board and pile length of sheet pile wall with relieving platform," Railway Engineering, vol. 11, pp. 74-77, 2011.

[26] Y. L. Hu, G. N. Liu, and Y. M. Zhao, "Calculation method of deformation and inner force of a sheet pile wall with relieving platform," in The Proceeding of Fourth International Conference on Transportation Engineering 2013 (ICTE 2013), ASCE, Chengdu, China, pp. 172-179, 2013.

[27] Y. L. Hu, G. N. Liu, and Y. M. Zhao, "Calculation on internal force and deformation of sheet pile wall with relieving platform," Subgrade Engineering, vol. 4, pp. 70-75, 2013.

[28] X. H. Chen, Structural Modeling Experiment of Brittle Material, China Water \& Power Press, Beijing, China, 1984.

[29] J. H. Cui, Geomechanical Model Test Method and Application of High Arch Dam, China Water \& Power Press, Beijing, China, 2008.
[30] X. S. Liu, Model Test and Dynamic Analysis of Large Shaking Table for Concrete Face Dam, China Water \& Power Press, Beijing, China, 2005.

[31] W. Z. Yuan, Similarity Theory and Statical Mode Test, Southwest Jiaotong University Press, Chengdu, China, 1998.

[32] H. Heinz, Model Analysis of Structures, Van Nostrand Reinhold Company, New York, NY, USA, 1974.

[33] J. Garnier, C. Gaudin, S. M. Springman et al., "Catalogue of scaling laws and similitude questions in geotechnical centrifuge modelling," International Journal of Physical Modelling in Geotechnics, vol. 7, no. 3, pp. 01-23, 2007.

[34] S. Iai, "Similitude for shaking table tests on soil-structure-fluid model in $1 \mathrm{~g}$ gravitational field," Soils and Foundations, vol. 29, no. 1, pp. 105-118, 1989.

[35] R. H. Hu, "Study on the mechanical behavior and failure mechanism for sheet pile wall with relieving platform," Ph.D Thesis, China Academy of Railway Sciences, Beijing, China, 2011.

[36] G. Y. Li, Y. S. He, Y. Q. Tao et al., Latest Practical Hardware Manual (Revised Edition), Guangdong Science and Technology Press, Beijing, China, 2011.

[37] X. F. Sun, Material Mechanics, China Science Publishing \& Media Ltd, Beijing, China, 2009. 